\title{
Las migraciones de Arturo Schomburg: Ser Antillano, Negro y Puertorriqueño en Nueva York. 1891-1917.1
}

\author{
Jesse Hoffnung-Garskof \\ Departamento de Historia y Departamento de Cultura Americana \\ Universidad de Michigan
}

J. Hoffnung-Garskof, "The Migrations of Arturo Schomburg: On Being Antillano, Negro, and Puerto Rican in New York, 1891-1917," Journal of

American Ethnic History 21, no. 1 (2001): 3-49.

Traducido por Edgardo Perez-Morales

Los historiadores recuerdan a Arturo Alfonso Schomburg principalmente por su magnífica colección de libros y documentos sobre historia y cultura negra. En 1926, Schomburg vendió su colección, originalmente guardada y catalogada en su casa de Brooklyn, a la Biblioteca Pública de Nueva York sentando así las bases de uno de los archivos más ricos del mundo para el estudio de la cultura negra. Schomburg fue también una figura pública visible en Harlem durante las décadas de 1920 y 1930, cuando colaboraba con intelectuales negros de élite tales como W.E.B. Dubois, Alain Locke y Charles S. Johnson; y servía como mentor de Langston Hughes, Claude McKay y otros escritores jóvenes del Renacimiento de Harlem. Desafortunadamente, la primera parte de la biografía de Schomburg es menos recordada. Él era, en el lenguaje de la época, un "Negro extranjero", ${ }^{2}$ nacido en la colonia española de Puerto Rico en

1. Traducción del ingles de Edgardo Pérez Morales. Quiero agradecer la lectura y las sugerencias que hicieron a los primeros borradores de este trabajo Arcadio Díaz-Quiñones, Jeremy Adelman, Paulina Alberto, Eduardo Elena, John Mack Faragher, Ben Goldfrank, Winston James, Barbara Krauthamer, Félix Matos-Rodríguez, Lorrin Thomas, Miriám Jiménez Román, y Juan Flores.

2. La palabra castellana Negro se usaba en el periodo (con mayúscula) para denominar a personas, culturas, y comunidades de ascendencia Africana en Estados Unidos. Era una denominación respetuosa, a diferencia de muchas palabras despectivas de la época. Los términos preferidos de los activistas e intelectuales de color, y de mayor uso entre la población en general, cambiaron. Hoy en día las palabras "black" (con o sin mayúscula) o "African American" (con o 
1874 de una mujer de las Indias Occidentales y un hombre descendiente de alemanes inmigrantes. Schomburg emigró a Nueva York en 1891 y allí logró integrarse en un pequeño enclave puertorriqueño en la floreciente comunidad de trabajadores cigarreros radicales e intelectuales nacionalistas cubanos. En los últimos años de su adolescencia y primeros de su veintena colaboró en la fundación de un club nacionalista revolucionario que tomaba su nombre de Cuba y Puerto Rico: "Las Dos Antillas."

La integración gradual de Schomburg en la vida intelectual y social negra norteamericana da cuenta de una historia no relatada aún acerca de la raza dentro de un pequeño grupo de migrantes cubanos y puertorriqueños en Nueva York entre 1890 y 1900. Durante la década de 1890, mientras su participación política en la causa de la independencia de Cuba y Puerto Rico alcanzaba su máximo apogeo, Schomburg contrajo matrimonio con una joven mujer de color originaria de Virginia y se mudó a un barrio afroamericano. Mientras las opciones para la independencia de Puerto Rico empeoraban y los conflictos nacionales, raciales y sociales dentro del movimiento separatista antillano se intensificaban, Schomburg se integró de una forma más completa dentro de la vida pública afroamericana, particularmente a través de actividades masónicas. Entre los Masones de Prince Hall encontró una comunidad de afroamericanos de clase media que era multiétnica, panafricanista y, como Schomburg mismo, experimentaba un pesimismo creciente acerca de las posibilidades de avance en cuestiones raciales mediante proyectos liberales, integracionistas y nacionales como el movimiento de independencia cubano. En la década que siguió al año 1898, Schomburg sostuvo algunos vínculos con activistas negros y mulatos en Cuba y Puerto Rico, con la esperanza de convertir dichos vínculos en una alianza internacional de intelectuales negros basada en Harlem. A medida que su lealtad política principal cambiaba del nacionalismo antillano al internacionalismo racial, también lo hicieron sus compromisos intelectuales. Dedicó su vida a reunir información sobre las contribuciones negras a la civilización mundial.

Tal vez porque no encaja de manera fácil en nuestras nociones contemporáneas acerca de lo que se debe esperar de la historia étnica, es decir, tempranas colonias de puertorriqueños o negros evolucionando claramente en posteriores "comunidades", cada una con sus propias ideas acerca de la identidad y de las políticas raciales; pero los historiadores le han dedicado sorpresivamente muy poca atención a la biografía de Schomburg. Desafortunadamente, los historiadores que han escrito sobre su vida han buscado a menudo establecer una relación entre el gran padre intelectual y las comunidades negras o puertorriqueñas contemporáneas, lo cual les ha llevado a pasar por alto la ambigüedad

sin guion) son las más comunes. Negro puede parecer un poco arcaico o hasta un insulto. 
y los cambios de identidad que son esenciales en su biografía. ${ }^{3}$ Estas interpretaciones adolecen de un deseo subyacente, y comprensible, de reivindicar el derecho a la memoria de Schomburg, pero además revelan un conflicto más profundo al que se enfrentan los historiadores al tratar de comprender su vida. Bajo la noción predominante de que negros y puertorriqueños han sido grupos étnicos separados, relativamente uniformes y claramente aglomerados a través del tiempo, Schomburg demuestra ser una figura difícil de comprender. ¿Era negro o puertorriqueño, o, en el mejor de los casos, un importante embajador de un grupo ante el otro? ¿O estaba su condición de puertorriqueño atenuada por los orígenes de su madre en la Indias Occidentales Danesas? ¿Fueron sus cambiantes creencias políticas raciales, como lo ha argumentado un académico, el resultado de que su más fuerte "identidad no hispánica” prevaleciera sobre su infancia puertorriqueña? ${ }^{4}$

La única respuesta satisfactoria a estas preguntas es una que, tal como ha argumentado Winston James, comprenda que Schomburg era al mismo tiempo puertorriqueño y negro. Además, sus vínculos con las Indias Occidentales subrayan el importante hecho de que él, como muchos de sus contemporáneos en el Renacimiento de Harlem, era producto de múltiples migraciones así como del desplazamiento colonial. En efecto, Schomburg lidió con una vertiginosa gama de identidades étnicas y nacionales: indiano occidental, español, puertorriqueño, cubano, estadounidense, antillano, africano, negro y, en un viaje a Europa, alemán. Ahora bien, no deberíamos detenernos ahí. Si mostrar que figuras como Schomburg, inmigrantes negros, fueron fundamentales en la formación de la vida intelectual de Harlem puede ayudarnos a ampliar los hori-

3. El trabajo de Elinor des Verney Sinnette sirve como cimiento fundamental para todos los trabajos biográficos sobre Schomburg. Pero ella lo define esencialmente como bibliófilo "negro" y por ende ve su patriotismo racial sencillamente como evidencia de su inteligencia y heroísmo intelectual. Elinor des Verney Sinnette Arthur Alfonso Schomburg, Black Bibliophile and Collector: a biography. (New York and Detroit: New York Public Library and Wayne State University Press, 1989), 2, 23. La autora puertorriqueña Flor Piñero de Rivera, asevera lo opuesto, argumentando que Schomburg era "primero" un gran puertorriqueño, y segundo un intelectual que descubrió "el legado histórico del negro." All his accomplishments after moving to Harlem are therefore the accomplishments Flor Piñeiro De Rivera, introducción a Arturo A. Schomburg. Arturo Schomburg: un puertorriqueño descubre el legado histórico del negro: sus escritos anotados y apéndices. ed. Flor Piñeiro de Rivera (San Juan: Centro de Estudios Avanzados de Puerto Rico y el Caribe, 1989).

4. Winston James, Holding Aloft the Banner of Ethiopia: Caribbean Radicalism in Early Tewntieth-Century America. (London, New York: Verso, 1998). 193-231. Sobre la supuesta tendencia "natural" de los puertorriqueñas de color a "rehuir ante cuanto pueda clasificarles en un grupo con una clase que sufre tal grado de injusticia y desprecio," véase Tomás Blanco, $E l$ prejuicio racial en Puerto Rico (Rio Piedras, P.R.: Ediciones Huracán, 1985) 103. También Lawrence Chenault. The Puerto Rican Migrant in New York City. New York: Columbia Universtiy Press. 1938. W.A. Domingo, "Gift of the Black Tropics," in The New Negro: An Interpretation. ed. Alain Locke, (New York: Albert and Charles Boni, 1925). 342. 
zontes de nuestro pensamiento sobre la etnicidad negra, ¿por qué no pedirle que haga lo mismo por nuestras ideas sobre etnicidad y migración puertorriqueñas? El resultado de sus migraciones puede ser único en muchos aspectos. Pero desvincular la evolución de la conciencia racial de Schomburg-James lo califica como una "aberración” puertorriqueña-de las vivencias raciales comunes entre los nacionalistas antillanos en Nueva York durante el cambio de siglo sería perder la oportunidad que ofrece su biografía para ayudarnos a repensar la historia de la raza de la migración puertorriqueña a los Estados Unidos. Igualmente, su historia puede contribuir a una revisión más amplia de los modelos comparativos de formación racial en las Américas para dar cuenta de los altos niveles de movilidad entre islas, comunidades nacionales y regiones de las que a menudo se piensa poseen sistemas discretos de pensamiento y políticas raciales. ${ }^{5}$

La biografía es de muchas formas la manera ideal para explicar este tipo de identidades grupales superpuestas, impredecibles o fluidas. Ahora bien, la historia de un hombre extraordinario, con todas sus migraciones e incertidumbres, sólo puede extrapolarse a una "comunidad" entera con gran precaución. En el caso de Schomburg la limitación más importante es la de la cronología. Durante sus primeros veinte años en Nueva York nunca hubo más que unos mil quinientos puertorriqueños en los Estados Unidos continentales. La primera gran migración de trabajadores y familias desde la isla comenzó a mediados de la década de 1920, cuando decenas de miles de migrantes puertorriqueños comenzaron a asentarse en East Harlem y Brooklyn. Para la década de 1930, cuando la noción del "puertorriqueño" emergió en las manos de líderes comunitarios y norteamericanos blancos racistas como una identidad étnica racial que no era ni blanca ni negra, Schomburg era un neoyorquino "negro" veterano. Mantenía algunas amistades con neoyorquinos hispanohablantes, pero vivía una vida alejada de las organizaciones sociales y políticas latinas. Pese a que los migrantes afropuertorriqueños durante estos años fueron menos pasivos en la construcción de una identidad puertorriqueña en Nueva York de lo que se ha presumido, no fueron guiados por Schomburg y tampoco siguieron, en su mayoría, su ejemplo.

Es difícil también extrapolar sus experiencias hacia la vida social de la isla de Puerto Rico en la década de 1890. Dado que la temprana migración puertorriqueña hacia el continente fue pequeña, la mayoría de la población isleña aún

5. Como parte de una visión global, de diáspora o trasnacional, los historiadores de la experiencia afroamericana en los Estados Unidos ahora mencionan a Schomburg con frecuencia. Véase Earl Lewis "To turn as on a pivot: Writing African-Americans into a History of Overlapping Diasporas.” American Historical Review 100:3 (Junio, 1995), 765-787 and Robin D. G. Kelley, "But a Local Phase of a World Problem.' Black History’s Global Vision", 1883-1950." Journal of American History. 86:3 (Septiembre 1999). 
vivía en el campo, y no compartió la experiencia de Schomburg como exiliado, nacionalista e inmigrante. Esto no quiere decir que no existieran vínculos entre sus experiencias en Nueva York y algunos centros locales de activismo en la isla. De hecho, Schomburg y sus más cercanos camaradas en Nueva York parece que entraron en la política mediante una importante alianza forjada en la década de 1870, y a inicios de los años ochenta entre artesanos urbanos y alfabetizados (especialmente tipógrafos y tabaqueros) y los movimientos abolicionista y de reformas coloniales en Puerto Rico. Tras unirse a la causa cubana, continuó su correspondencia con grupos de artesanos y liberales en Ponce y otros centros urbanos. Aún así, Cuba figuraba más prominentemente que Puerto Rico de muchas maneras en las tempranas actividades intelectuales y políticas de Schomburg en Nueva York. Durante la década de 1890, Schomburg, junto con un grupo multirracial de exiliados puertorriqueños de clase trabajadora, se adhirió a la más amplia comunidad cubana en Nueva York. Ellos ayudaron a construir una política nacionalista de clase y raza que resonaba de una forma más cercana a los profundos conflictos sociales de Cuba que con la relativa calma de Puerto Rico. Para este puñado de exiliados puertorriqueños la alianza con los cubanos era en sí misma un importante y duramente debatido símbolo, tanto de su nacionalismo, como de sus progresivas agendas raciales y de clase. A menudo, los intelectuales cubanos permanecieron fieles a sus políticas nacionalistas o socialistas multirraciales (sintiéndose, comparativamente, menos atraídos por mensajes fuertes de nacionalismo negro que, por ejemplo, los jamaiquinos en la década de los 20). Pero en los círculos puertorriqueños y cubanos que Schomburg frecuentaba en Nueva York, este nacionalismo que supuestamente no entendía de razas era campo de cultivo para un intenso conflicto sobre la raza y la historia.

¿Por qué la historia? El movimiento de la independencia antillana en Nueva York estaba empapado en ideales liberales decimonónicos sobre la importancia de las naciones en el curso del progreso y la civilización universal. Dentro del movimiento, activistas de color y artesanos habían trabajado para construir sus propias historias, dando un lugar esencial a la raza negra y a la clase obrera en el progreso nacional. Aun dentro de su nacionalismo, que no conocía oficialmente de razas, algunas veces usaban un lenguaje que prefiguraba la más tardía Historia negra de Schomburg. Posteriormente, a medida que sus esperanzas por una República de Puerto Rico comenzaban a desbaratarse, Schomburg y sus compañeros se enfrentaron a un dilema común: la necesidad de establecer cimientos sólidos de pertenencia nacional y étnica en un mundo desfigurado por la dominación colonial y el racismo. Si Schomburg era alguien poco común entre los veteranos del movimiento revolucionario antillano, no lo era por la intensa energía que le dedicaba a la compilación histórica, ni siquiera por imaginar una alianza entre negros hispanos y norteamericanos. Era único 
en la medida en que su pasión por la historia y su compromiso con una nueva alianza internacional negra lo impulsaron a destacar en instituciones sociales negras de clase media en Nueva York.

La entrada de Schomburg en la vida social de la clase media negra en Nueva York, después de 1898, es tal vez la más llamativa e inusual de sus migraciones. Los observadores se han maravillado con frecuencia por la cantidad de puertorriqueños de color en Nueva York que se esforzaban sobremanera para evitar ser "confundidos" con norteamericanos negros, en un intento por evitar la trampa de la cada vez más estricta línea que separaba los colores. Pero Schomburg hizo exactamente lo contrario. Deliberadamente se identificaba a sí mismo como negro y, de forma extraña, encontró un lugar detrás de esa línea que separaba los colores para garantizar su movilidad social durante tres décadas. La segunda migración de Schomburg (a la Norteamérica negra), tal como su primera migración (al corazón mismo del Partido Revolucionario Cubano en Nueva York), fue el resultado de sus aspiraciones a una política racial progresiva que aún no existía en Puerto Rico. Este interés estaba probablemente inspirado, en parte, por su herencia de las Indias Occidentales. Ahora bien, su segunda migración fue también una forma de expresar ambiciones de clase y aspiraciones intelectuales. Tales aspiraciones eran lo bastante comunes entre los círculos revolucionarios de su juventud, pero Schomburg logró satisfacerlas al trasladarse hacia el internacionalismo negro. El mulato colonial exiliado se convirtió en un negro, un ciudadano de segunda clase en el país más rico y poderoso del mundo. El infatigable historiador se convirtió en un famoso intelectual negro.

Aplicar la idea de "diásporas entrecruzadas" a la migración y a la historia de la raza y la etnicidad en Nueva York probablemente satisfaría el deseo de Schomburg de fomentar el estudio de la historia negra desde una perspectiva internacional. Pero si esperamos usar la biografía de Schomburg para reafirmar la importancia de la diáspora en la historia de la etnicidad, deberíamos ser cuidadosos y no definir diáspora tal como él lo hizo, como una verdad eterna que puede descubrirse con la investigación histórica objetiva. En cambio, deberíamos mejor comprender la diáspora como una serie de ideas más bien espinosas acerca de la pertenencia y el desplazamiento que ha surgido de la experiencia moderna de la esclavitud Atlántica, el colonialismo, la emancipación y la migración, y que se ha desarrollado en diálogo con discursos dominantes sobre la raza y la nación. ${ }^{6}$ En este sentido Schomburg no fue simplemente el ejemplo de un migrante cuya etnicidad e identidad racial fueron moldeadas por experiencias de diáspora; fue también un constructor activo de la idea de diáspora que hemos heredado. Su archivo, miles de libros y manuscritos de todas las

6. Paul Gilroy, The Black Atlantic Modernity and Double Consciousness. (Cambridge: Harvard University Press, 1993) 1-40. Colin Palmer “Defining the Modern African Diaspora," Perspectives. 36:9 (Septiembre 1998), 1, 22-25. 
esquinas del mundo negro imaginado por él, no refleja una verdad histórica abstracta acerca de la unidad de toda la gente negra, sino más bien sus preocupaciones, sus migraciones, y sus relaciones, es decir aquello que los estudiosos de la literatura llamarían su "posición de sujeto". Así, si los acontecimientos de la vida de Schomburg pueden proporcionar evidencias para apoyar un acercamiento flexible e internacional a la etnicidad, las líneas de su trabajo pueden también proporcionar los fundamentos de una historia intelectual de ese mismo acercamiento. La corta biografía que sigue es también, en ese sentido, la genealogía de un archivo que sigue dando forma a la consciencia histórica contemporánea acerca de los estudios negros, y en particular a nuestras nociones actuales sobre la diáspora Africana. ${ }^{7}$

\section{"Para que los derechos del pueblo sean reales y no una vaga ficción los derechos del pueblo" Clase, Raza y nacionalismo puertorriqueño en el Partido Revolucionario Cubano, Nueva York, 1891-1898}

Durante la Guerra de los Diez Años cubana (1868-1878) y su posguerra, "colonias" de cubanos exiliados y refugiados, huyendo de la guerra y de la persecución política, aparecieron en ciudades del Caribe y alrededor del Atlántico Norte: París, Madrid, Santo Domingo, Kingston, Cayo Hueso, Filadelfia y Nueva York. Muchos en esta "emigración" eran oponentes activos al régimen colonial español. Establecieron redes de correspondencia y actividad revolucionaria para conectar sus comunidades dispersas. Otros simplemente esperaban proteger a su gente y sus inversiones de los estragos de la guerra. Durante la década de 1880 la creciente migración cubana al sur de la Florida y Nueva York vino a incrementarse gracias a las leyes tarifarias de los Estados Unidos que favorecían la importación de tabaco en rama sobre los cigarros manufacturados. Cigarreros cubanos trasplantaron sus fábricas y trabajadores a Cayo Hueso, Tampa y la ciudad de Nueva York, un traslado que tuvo la consecuencia imprevista de establecer centros de activismo obrero dentro de la "emigración" y cambiar la complexión del movimiento nacionalista en el extranjero. ${ }^{8}$ Puerto Rico se salvó tanto los beneficios como el trauma de la extendida guerra anticolonial de esos años. Aún así, olas periódicas de violencia autoritaria en contra de liberales y separatistas produjeron un número más reducido de refugiados

7. Kelley, "But a Local Phase of a World Problem", nota la influencia profunda de la colección de Schomburg, y por ende su biografía, sobre las ideas de intelectuales afroamericanos acerca de la historia internacional.

8. Gerald Poyo, With All and for the Good of All: The Emergence of Popular Nationalism in the Cuban Communities of the United States, 1848-1898. (Durham, NC: Duke Universty Press, 1989), 52-55. 
políticos, muchos de los cuales se unieron a las más grandes colonias cubanas esparcidas por el mundo. Muchos, por ejemplo, abandonaron Puerto Rico en 1887 tras los arrestos y torturas masivos de artesanos acusados de conspirar para boicotear a los comerciantes españoles. En Nueva York, trabajadores cigarreros exiliados conocidos como tabaqueros, y otros refugiados de clase obrera, establecieron su propio enclave en conexión con la más grande "colonia" puertorriqueña y con las instituciones políticas y sociales de los tabaqueros cubanos. Fue a este enclave al cual Arturo Schomburg, un aprendiz de diecisiete años de edad en una imprenta de San Juan, llegó en 1891. Traía consigo una carta de presentación firmada por su jefe, un editor liberal llamado José González Font. Schomburg desembarcó de un navío de vapor en el puerto de Nueva York y salió en busca de amigos tabaqueros, quienes le ayudaron e encontrar un sitio donde hospedarse y una manera de sobrevivir. ${ }^{9}$

Al inicio Schomburg vivió entre nacionalistas puertorriqueños y cubanos de la parte baja de la Segunda Avenida, mientras que estudiaba inglés por las noches. Pero después de sólo cuatro años en Nueva York, a los veintiún años de edad, contrajo matrimonio con Elizabeth Hatcher, una afroamericana de Virginia de tez clara. Con Elizabeth y sus tres hijos; Máximo Gómez, Arturo Jr. y Kingsley Guarionex, vivió en la Calle 62 Oeste, en el barrio negro conocido como San Juan Hill. Cuatro años después de haber llegado a Nueva York era padre y esposo en un hogar donde el inglés, presumiblemente marcado por un gangueo sureño, era la lengua de su esposa, de sus hijos y de sus parientes políticos. De Hatcher, quien murió en 1900, y de sus dos esposas siguientes (ambas negras y nacidas en Estados Unidos de familias de habla inglesa) y sus familias debió de haber aprendido música, baile, bromas y folclor norteamericano negro, al igual que pautas de parentesco y redes sociales. Desde luego, aprendió también sobre gastronomía afroamericana y aparentemente desarrolló un gusto considerable por la misma, habiéndose propuesto en algún momento de su vida investigar y escribir un libro de cocina e historia social de la cocina negra. A juzgar por sus descripciones notablemente personales desde "los sustanciosos panes de huevo y manzanas horneadas en azúcar de Virginia,

9. César Andreu Iglesias, ed. Memorias de Bernardo Vega: contribución a la historia de la comunidad puertorriqueña en Nueva York, (Río Piedras, P.R., Ediciones Huracán, 1977), 106. Carta de presentación firmado por José González Font. 2 de abril, 1891. Schomburg Center for Research in Black Culture, New York, NY, Arthur A. Schomburg Papers (SSRBC, Schomburg). Hay datos sobre González Font en Sotero Figueroa, Figueroa, Sotero. Ensayo biográfico de los que más han contribuido al progreso de Puerto-Rico. (Ponce, Puerto Rico: Establecimiento Tipográfico el Vapor, 1888). Sobre la Guerra de los Diez Años véase Ferrer, Ada. Insurgent Cuba: Race, Nation, and Revolution, 1868-1898. (Chapel Hill: University of North Carolina Press, 1999) y sobre la política anti-colonial en Puerto Rico Jiménez de Wagenheim, Olga. El grito de Lares, Sus causas y sus hombres (Río Piedras: Ediciones Huracán, 2004). Atrid Cubano Iguina, Astrid. "Political Culture and Male Mass-Party Formation in Late-Nineteenth-Century Puerto Rico." Hispanic American Historical Review, (Septiembre, 2008). Delgado Pasapera, Germán. Puerto Rico: Sus Luchas Emancipadoras (1850-1898). Río Piedras: Editorial Cultural, 1984. 
a los sesos en mantequilla morena y tortas rebozadas con sus costados de crujientes bordados negros del Blue Grass, hasta las calas de arroz y los inefables cafés macerados, chocolates con sabor a canela y toddies calientes servidos en la mañana tras las celosías iluminadas por el sol de la Vieux Carre en Nueva Orleans-y en especial en la casa" de su amigo W. W. Cohen, había dedicado horas de amorosa investigación al estudio de los logros de la gastronomía negra en compañía de familiares y amigos. La vida familiar, si bien escasamente registrada en los documentos de Schomburg, sirve de esta forma como un telón de fondo importante para su vida pública posterior entre los norteamericanos negros. ${ }^{10}$

Este era una patrón relativamente común entre exiliados cubanos y puertorriqueños de color en las décadas de 1880 y 1890, quienes, mientras que sus compatriotas de tez más clara se mezclaban entre la inmensa multitud de blancos extranjeros, tenían pocas opciones además de asentarse en edificios y vecindarios reservados para la pequeña minoría negra de Nueva York. Allí se hospedaban con frecuencia y llegaban a formar familias con vecinos afroamericanos de los Estados Unidos. Fue desde la perspectiva de esta experiencia segregacionista y de estas conexiones con negros angloparlantes, que cubanos y puertorriqueños de color participaron en el mundo de los emigrados políticos, incluyendo el Partido Revolucionario Cubano y su Sección Puerto Rico. Las considerables energías políticas de Schomburg durante su primera década en Nueva York, fueron consumidas por movimientos de exiliados. En posteriores ensayos y cartas, Schomburg se refería con frecuencia a José Martí y al líder afrocubano Rafael Serra como colaboradores cercanos y amigos personales: "[Yo] era amigo del inolvidable Martî", escribió a un historiador cubano el mes antes de su muerte en 1938, "llegué a gozar de la inspiración que nos animaba durante los primeros días de la formación del Partido Revolucionario Cubano en Nueva York." ${ }^{11}$ En cartas a Juan Gualberto Gómez de 1915 y 1927, le recordaba al estadista cubano su encuentro en la casa de "nuestro amigo" Rafael Serra (una casa ubicada, de hecho, en un distrito poblado por afroamericanos e Indianos Occidentales). Posteriormente, en un artículo de 1933 que apareció en Opportunity, describió a Gómez como su amigo desde inicios de la década de $1890 .{ }^{12}$ Puede sospecharse que exageró algunas veces la importancia de su

10. SCRBC, Schomburg. Hoffnung-Garskof, Jesse. "The World of Arturo Schomburg: AfroLatinos, African Americans, and the Antillean Independence Movement, 1879-1914." In AfroLatin@S in the United States: A Reader, edited by Miriam Jiménez Román and Juan Flores. (Durham, NC: Duke University Press, 2009). 70-91.

11. A.A. Schomburg. carta a Emilio Roig de Leuchsenring. 14 de mayo, 1938. SCRBC, Schomburg.

12. Véase el curriculum de Schomburg, sin fecha pero probablemente escrito entre 1898 y 1906, John Edward Bruce Papers, Schomburg Center for Research in Black Culture, New York, NY (SCRBC, Bruce). Años después Schomburg relató que descubrieron un plan de atentado contra Martí mientras todos estaban en una reunión en la casa de Sotero Figueroa en la Se- 
papel dentro del movimiento al presentarse a sí mismo como el secretario de la "Junta Cubana" (que con certeza no lo era), y al haber asegurado que había ayudado a salvar a Martí de un intento de asesinato (lo cual pudo ser cierto). ${ }^{13}$

Pese a que sus relaciones con Martí, Gómez y Serra fuesen de amistad cercana o no, Schomburg era un organizador activo en los primeros días de la formación del Partido Revolucionario Cubano. En 1892, junto con el tabaquero negro puertorriqueño Rosendo Rodríguez y varios tabaqueros negros cubanos, Schomburg colaboró en la fundación de un club revolucionario en Nueva York llamado "Las Dos Antillas.” Posteriormente sirvió como secretario de actas del club (Rodríguez se convirtió en presidente). Junto con "Borinquen", liderado por Sotero Figueroa, y un club de mujeres llamado "Mercedes Varona", liderado por las esposa de Figueroa, "Las Dos Antillas" era uno de los tres clubes revolucionarios creados por el enclave puertorriqueño dentro de la comunidad cubana de Nueva York. ${ }^{14}$

Constituidos fundamentalmente de tabaqueros, los clubes revolucionarios puertorriqueños en Nueva York se ocupaban principalmente en el proyecto de recaudar fondos para el Partido Revolucionario Cubano en "las fábricas". Pero también eran el hogar de la política radical y de la vida intelectual obrera que descendía de los casinos de artesanos y de gente de color y sociedades mutuales que habían emergido en la isla a finales de los años 1860. Schomburg venía de este mismo mundo de artesanos autodidactas. Según el dirigente obrero radical puertorriqueño Bernardo Vega, "recibió las primicias de la educación" entre tabaqueros. De hecho, su madre procedía de una familia de color libre y de estatus relativamente alto en Saint Croix, y Schomburg parece que recibió educación clerical o posiblemente en una escuela pública. ${ }^{15}$ Posteriormente se hizo aprendiz en la imprenta de José González Font, uniéndose así a los escala-

gunda Avenida. Según contó, el joven Schomburg, Rosendo Rodríguez y Gonzalo de Quesada acompañaron a Martí a su casa, salvándole la vida. Véase "General Antonio Maceo" The Crisis. (May, 1931). Carta de Schomburg a Emilio Roig de Leuchsenring. 14 de Mayo, 1938. SCRBC, Schomburg. Para su amistad con Gómez véase A.A. Schomburg. "My Trip To Cuba in Quest of Negro Books." Opportunity. (Febrero, 1933) y las cartas de Schomburg a J.G. Gómez, 22 de enero, 1915 and 22 de septiembre, 1927. Archivo Nacional de la Cuba, Fondo Adquisiciones, Caja 45, Signatura 3567.

13. Un fragmento de un períodico sureño no identificado anuncia la visita de un "Caballero Cubano, Arthur Schomburg," probablemente un viaje en 1898 o poco después. SCRBC, Schomburg.

14. Ibrahím Hidalgo Paz, "Reseña de los clubes fundadores del Partido Revolucionario Cubano." Anuario del Centro de Estudios Martianos. 4 (1981) 208-230. "Reglamento del Club Político Las Dos Antillas" en el Libro de Actas del Club Las Dos Antillas (1892-1895). SCRBC, New York, NY, (SCRBC, Antillas).

15. Andreu Iglesias, Memorias de Bernardo Vega. 243. Des Verney Sinnette, Arthur Alfonso Schomburg, 7-17. Sobre Figueroa y Marín véase Jesse Hoffnung-Garskof, "To abolish the law of castes: merit, manhood and the problem of colour in the Puerto Rican liberal movement, 187392," Social History, 36:3, (August 2011). 312-342. 
fones superiores de la clase obrera urbana. Los tipógrafos no eran únicamente los más educados entre los trabajadores urbanos, sino que además disfrutaban a menudo de estrecho contacto con los autores principales de la isla, muchos de los cuales abogaban también por la educación y el avance de los artesanos. Los editores liberales a menudo protegían a los artesanos ejemplares, apoyando sus clubes sociales e incluso presentándoles ante círculos literarios. Sotero Figueroa y Francisco Gonzalo Marín, quienes fundaron Borinquen juntos, eran tipógrafos mulatos que habían ascendido en los rangos de las imprentas liberales hasta convertirse en periodistas y autores. Este contexto explica el posterior relato de Schomburg sobre su aprendizaje de la historia puertorriqueña con el notorio abolicionista y autor liberal Julián José Acosta, que también era dueño de una imprenta importante en San Juan. ${ }^{16}$ Como tipógrafos y autores en ciernes, Schomburg, Figueroa y Marín, hombres que no habían ido a la escuela secundaria, desarrollaron aspiraciones de grandeza literaria y de heroísmo nacional que estaban, en muchas formas, animadas por posiciones liberales puertorriqueñas sobre raza y clase. Los hombres de méritos intelectuales deberían, argumentaban Acosta y sus aliados, ser tratados como iguales sin importar sus orígenes sociales. En Ponce en la década de 1880, tanto Figueroa como Marín lograron convertirse en hombres de una posición pública modesta. Schomburg, como tipógrafo, quizás podía aspirar a una posición de autor e intelectual parecida. ${ }^{17}$

Aun mientras gestionaban su propia ascendencia social, los líderes eventuales del movimiento exiliado en Nueva York también mantenían nexos con grupos artesanos emergentes en poblados de artesanos urbanos cualificados, la mayoría de los cuales eran hombres de color. Figueroa fue arrestado en 1883, por ejemplo, mientras daba un discurso en el Centro de Recreo e Instrucción para Artesanos y Obreros en el municipio de Juana Díaz. Marín ayudó a una facción radical de autonomistas a reclutar artesanos y obreros para un boicot a los negocios españoles en 1887. La idea de clase, en particular la clase artesana, que tenía también una estrecha asociación con hombres urbanos de color, también jugó un rol crucial en los esfuerzos organizativos de estos hombres cuando emigraron a Nueva York. "[E]ste movimiento Redentor," anunció Figueroa ante la primera asamblea del Partido Revolucionario Cubano, "no arranca de las clases privilegiadas". Figueroa describió un movimiento más bien modelado según Jesucristo, un carpintero humilde que "se lanza pobre y oscuro, solo é indefenso, á través de la Judea, á levantar en los corazones el imperio de la justi-

16. Sobre sus estudios con Acosta véase A. Schomburg, "In Search of Juan de Pareja," The Crisis. (Julio, 1927). 153.

17. Hoffnung-Garskof, "To abolish the law of castes." Sobre el proyecto de recaudar fondos en las fábricas véase el libro de actas de Club Las Dos Antillas, 21 de mayo, 1895, y 27 de agosto, 1895. SCRBC, Antillas. 
cia, á abolir la ley de casta, predicando el dogma iluminador de las conciencias y dignificador de la humanidad, que se encierra en estas tres sublimes palabras: Libertad, Igualdad, Fraternidad."18

Mientras tanto, los mismos líderes de clubes que recaudaban ayudas económicas en las fábricas de tabaco para adquirir armas para expediciones a Cuba, y que celebraban el sacrificio de la clase obrera por la causa del nacionalismo, respondían a la vulnerabilidad económica periódica de los obreros en el exilio. Los líderes de Borinquen y Dos Antillas actuaban como intermediarios ante la caridad de la élite dentro de la comunidad de emigrados. Durante el pánico económico de 1893, por ejemplo, Schomburg y los demás líderes de Las Dos Antillas convocaron una reunión para discutir las formas en que podía sostenerse a las familias de emigrados que padecían extrema pobreza. Se retractaron de dicha convocatoria cuando oficiales españoles comenzaron a difundir la noticia de que el movimiento revolucionario estaba flaqueando ante el reto de las dificultades económicas, pero a cambio lograron de los emigrados más ricos la promesa de que algunos de los recursos de la comunidad cubana se dedicarían a proteger a las familias pobres. "Nuestros pobres en nueva York", anunciaron en Patria, "serán auxiliados por sus hermanos de todos rangos y matices." 19

Si bien los llamados para la reforma social (o la ayuda mutua) entre activistas obreros tabaqueros en el movimiento nacionalista se articulaban a menudo como una política de clase, la igualdad racial y la armonía racial eran también elementos importantes en las políticas articuladas por los líderes de clubes. (Debería recordarse también que, especialmente para los puertorriqueños, la noción de artesano como una categoría de clase era inseparable de la cuestión de las castas). Los clubes revolucionarios en Nueva York predicaban sus políticas sobre la visión de una nacionalidad cubana racial y socialmente democrática articulada por el líder cubano José Martí. Cubanos de todas las razas (que no de ambos sexos), escribió Martí, compartían un carácter nacional común: eran generosos, ilustrados, patrióticos y varoniles. Y puesto que la verdadera unidad social y política derivaba de valores compartidos, creencias compartidas, e intereses compartidos y no del color de piel compartido, las similitudes nacionales de los cubanos superarían siempre con creces cualquier antagonismo racial que pudieran abrigar. "Los hombres verdaderos", proclamó Martí, "blancos y negros, se tratarán con lealtad y ternura, por el gusto del mérito y el orgullo de todo lo que honre la tierra en que nacimos, negro o blanco."20

18. S. Figueroa en Suplemento al No. 7 de Patria "Discursos Pronunciados en la Confirmación de la Proclamacion del Partido Revolucionario Cubano, Hardman Hall, 17 de abril, 1892." Hoffnung-Garskof, "To abolish the law of castes."

19. Gabriel López, F. G. Marín, Federico Pacheco, F.J. Prieto, Narciso García, Silvestre Bressman, S. Pivaló, Isidoro Apodaca, Antonio Molina, Rosendo Rodríguez, Arturo Schomburg. "A los Cubanos y Puertorriqueños residentes en New York." Patria, 22 de agosto, 1893.

20. José Martí. "Mí Raza." Patria. 23 de marzo, 1894. 
En el contexto intensamente racista de las sociedades cubana y puertorriqueña, donde la esclavitud había sido abolida sólo en las décadas de 1870 y 1880, los intelectuales cubanos de color acogieron esta aparente neutralidad racial y la promesa de ciudadanía total. Muchos de ellos formaron amistades profundas y duraderas con Martí. Pero los discursos y ensayos de Martí, ahora canonizados como los textos fundacionales de la "democracia racial" cubana, eran parte de una tendencia intelectual más amplia entre los separatistas cubanos blancos y liberales. En las décadas de 1880 y 1890 estos pensadores blancos, y hasta escritores de color como Enrique Medin Arango, escribieron multitud de nuevas historias de las guerras de independencia de Cuba buscando contradecir las repetidas acusaciones de la prensa española sobre la insurgencia cubana como una guerra de odio racial emprendida por negros despiadados. Al contrario, argumentaban, los líderes independentistas blancos se habían ganado la lealtad de sus esclavos mediante actos desinteresados de manumisión mientras que ellos mismos, "todavía esclavos" de la tiranía española, "tuvieran la abnegación de salvar á sus hermanos, [los esclavos] — que materialmente sufrían más que ellos, —-salvando al propio tiempo sus ilustradas conciencias." ${ }^{21}$ Este acto de sacrificio y generosidad había absuelto a la nación cubana de la mancha de la esclavitud y en respuesta los negros habían probado estar eternamente agradecidos siguiendo con lealtad a sus antiguos amos hacia el campo de batalla para forjar una nación cubana. Este era un mensaje reconfortante para los blancos nacionalistas, muchos de los cuales tenían un tenue compromiso con la igualdad racial. Los propios escritos de Martí, si bien prometían ciudadanía total, desalentaban la formulación de reclamos explícitos de reparaciones raciales como algo contrario al espíritu de la hermandad racial. ${ }^{22}$

Así, la neutralidad racial en el movimiento nacionalista cubano se predicaba sobre la construcción de una nueva imagen de los negros no como africanos sedientos de sangre sino como cubanos negros pasivos, agradecidos y que no representaban una amenaza. Pero cubanos de color como Medin Arango, Serra y Gómez se apropiaron de los ideales de democracia racial, al igual que de los relatos de lealtad y sacrificio negros, para sus propios proyectos de avance racial e igualdad de derechos. Narraron la historia del movimiento de independencia en sus propios términos. Era cierto que los cubanos de color se habían lealmente sacrificado en las guerras anteriores, argumentaban, pero esto no era símbolo de su gratitud hacia aquellos que los habían tenido por esclavos. Era más bien la marca del heroísmo nacional y el mérito por los cuales debían de ser recompensados con la ciudadanía total. Dentro del supuesto mundo racialmente neutral del movimiento nacionalista, líderes cubanos de color y alia-

21. Enrique Medín Arango. Discurso pronunciado en la velada inaugural de la Sociedad de Instrucción y Recreo Porvenir por el cíudadano Enrique Medín Arango. La Noche del 3 de Agosto, de 1896. (Key West: Imprenta “El Discípulo," 1896) 33-34

22. Ferrer, Insurgent Cuba. 
dos blancos progresistas se disputaban las historias. Los puertorriqueños en el movimiento participaron también en el debate sobre raza y sacrificio. Sotero Figueroa tipografió y publicó el libro Héroes humildes, de Serafín Sánchez, que presentaba perfiles de héroes de la guerra de los Diez Años de diferentes clases y colores. El perfil del cautivo africano convertido en insurgente cubano José Antonio Legón concluye: "Negros y blancos: honrad al hombre libre que murió defendiendo la libertad de todos, id allí al suelo consagrado por el sacrificio y por la sangre y seréis iguales a José Antonio Legón, que para mi corazón y mi justicia vale más que todos los blancos y todos los negros que no igualaron su gloria de hombre verdadero." Francisco Gonzalo Marín, el tipógrafo y poeta mulato que ayudó a fundar Borinquen, se convirtió casi en una celebridad en los círculos de exiliados de Nueva York por su apasionada visión de redención mediante la violencia y el sacrificio. ${ }^{23}$

Al mismo tiempo, y a pesar de las advertencias de Martí sobre el separatismo negro, los cubanos de color mantuvieron instituciones políticas y sociales independientes en el Directorio de Sociedades de Color como espacios de organización política antirracista y programas de educación popular. Tal como los clubes de artesanos en Puerto Rico, estas sociedades proponían socializar y elevar las masas negras preparándolas así para la ciudadanía. Serra creó una de estas sociedades en Nueva York, La Liga, "Sociedad protectora de instrucción, consagrada al auxilio de la clase de color." Más que educación popular, La Liga se proponía ayudar a hombres de color que poseyeran los fundamentos de aprendizaje y aptitudes para aspirar a "carreras ú oficios pocos comunes aún en la clase de color." ${ }^{24}$ La Liga parece haber impulsado ambiciosos artesanos de color con talento hacia papeles de liderazgo en el PRC. En efecto, el presidente del club, Las Dos Antillas, Rosendo Rodríguez, era miembro de La Liga como también lo eran otras figuras importantes del liderazgo de Las Dos Antilla y Borinquen. En las manos de Serra, Figueroa, Marín, y otros en esta comunidad, Martí (quien asistía semanalmente a La Liga para enseñar literatura y composición a artesanos intelectuales en ciernes) se convirtió en el símbolo de una agenda nacionalista popular para el avance racial y la transformación social, el triunfo de un sistema de recompensas sociales basado en el sacrificio y el mérito, no en el "vicio" colonial del prejuicio de castas. "Desde la extrema izquierda del Partido Separatista," escribía Serra, "y en conformidad con los preceptos aceptados por todos, hemos de dirigir nuestros esfuerzos para el triunfo de la Independencia de la patria, y para que sean reales y no una vaga ficción los derechos del pueblo."25

23. Serafín Sánchez, Héroes Humildes. (Nueva York: Imp. S. Figueroa, 1894), 43. Sobre la importancia de violencia y sacrificio en la ideología de Martí váase Louis A. Pérez, To Die in Cuba: Suicide and Society. (Chapel Hill: University of North Carolina Press, 2005).

24. Rafael Serra. Ensayos políticos, sociales, y económicos. Tercera Serie. (New York: Imprenta de A.W. Hawes, 1899), 151-152.

25. Rafael Serra. Ensayos políticos. Segunda serie. (New York: Imprenta de P.J. Díaz. 1896), 134. 
Este contexto ayuda a entender la naturaleza de las actividades políticas de Schomburg durante la década de 1890 . Si bien las discusiones sobre clase y casta fueron relativamente escasas en las actas de reuniones de Las Dos Antillas, las actas de una reunión de octubre de 1895 sugieren la manera en que la raza (a veces solapada con la clase y a veces como una categoría diferente) se manifestaba en el pensamiento de sus miembros. Aquella noche Las Dos Antillas se reunió conjuntamente con Borinquen en el Military Hall para celebrar la llegada de dos compañeros puertorriqueños, Gerardo Forrest y Gumersindo Rivas, tras una estancia en la colonia de exiliados en Venezuela. Después de unas palabras de agradecimiento por parte de Forrest y Rivas, un compañero cubano identificado como Agramonte subió a la tarima y sugirió que se construyera un monumento a los artesanos que habían introducido "los principios de libertad" y "las ideas avanzadas" en el proyecto de independencia nacional. El heroísmo artesano y el sacrificio militar, que "son los que han hecho la guerra de los 10 años," justificaban un lugar central en la memoria del movimiento. Tras unas palabras de Juan Terraforte (veterano del fallido levantamiento de Lares en 1868), Hanibal A. Castro, un colombiano voluntario en el ejército Mambí, tomó la palabra. España, le dijo a la audiencia, había apelado a sentimientos racistas para perjudicar la causa cubana. Pero en Colombia y Venezuela "la negra es la raza privilegiada, la que triunfó en Carabobo y Ayacucho [sic]." Continuó diciendo que "la raza negra, la generosa, la viril, la valiente, tuvo su cuna en Egipto, patria del Negro." El Egipto negro era el lugar de nacimiento de la civilización y el progreso, le advirtió a la audiencia. Las pirámides colosales construidas por los egipcios negros nunca habían sido replicadas, ni siquiera por la más inteligente de las mentes modernas. ${ }^{26}$

Tal discurso, si bien procedente de una larga historia de militancia parda en Colombia, probablemente se hubiera ganado una recepción hostil por parte de los intelectuales y políticos líderes de Bogotá en aquel entonces. ${ }^{27}$ Pero entre los hombres de Las Dos Antillas y Borinquen fue acogido con calidez. Schomburg ciertamente debió haberlo disfrutado. En una entrevista en los años veinte recordaba haber formulado argumentos semejantes ante amigos que asistían a las lecciones de historia de Acosta en San Juan unos años antes de emigrar. Algunos chicos blancos lo había provocado con el argumento de que los negros puertorriqueños no tenían historia, de manera que él se había dedicado a encontrar ejemplos que probaran lo contrario. ${ }^{28}$ Él y los demás miembros de la

26. Asamblea extraordinaria en "Military Hall" 6 de octubre, 1895, SCRBC, Antillas.

27. Marixa Lasso. Myths of Harmony: Race and Republicanism During the Age of Revolution, Colombia 1795-1831, (Pittsburgh, PA: University of Pittsburgh Press, 2007). Peter Wade. Blackness and Race Mixture:The Dynamics of Racial Identity in Colombia. (Baltimore: Johns Hopkins University Press, 1993). 9-47.

28. Gustavo Urrutia, "Schomburg" in Diario de la Marina, 2 de noviembre, 1933. Según Winston James este artículo se basó en otra biografía corta de Schomburg, Floyd Calvin, "Race Colleges need Chair in Negro History-A.A. Schomburg," in the Pittsburgh Courier, 5 de marzo, 1927. 
asamblea conjunta de Las Dos Antillas y Borinquen comenzaron a responder enérgicamente. "En la línea de los Reyes Españoles", dijo Castro, "hubo sangre de negro." "Bravo!", respondió la multitud. "Y hoy un negro es el primer cubano," "Bravo," interrumpieron. "Maceo." Concluyó Castro. "Viva Maceo!" gritó una voz, y la multitud respondió con un enfático “Viva!”. Los hombres de Bonrinquen y Las Dos Antillas aclamaban la idea de que la raza negra era protagonista central de su movimiento de independencia y de ese gran relato de civilización y progreso que guardaban con tanto amor en sus corazones liberales. Cuando Castro repitió su promesa de arriesgar su vida para unirse a Maceo en la batalla, "Una lluvia," escribió Schomburg en las actas, "puede decirse de aplausos zozobró las elocuentes palabras del hijo de Colombia." 29

Sotero Figueroa era el siguiente orador. Resumiendo, su ensayo "La verdad de la historia" entregaba una historia diseñada para vindicar el rol de Puerto Rico en el movimiento mientras que concebía el movimiento de independencia como una lucha internacional por la justicia racial. El origen de la unión entre Cuba y Puerto Rico era la comisión conjunta a Madrid de 1867, dijo. En tal misión los representantes puertorriqueños habían recomendado la abolición de la esclavitud mientras que los cubanos sólo habían pedido una mejoría de las condiciones de la misma. La guerra de los Diez Años, continuó, había fracasado en terminar la esclavitud en Cuba mientras que el Grito de Lares había originado la emancipación total. Cada uno de estos ejemplos probaba, aseguró, que Puerto Rico no era un mero espectador pasivo de la lucha revolucionaria. Más allá de su arenga, la reformulación de la historia planteada por Figueroa muestra una suposición abierta de que la lucha independentista era un movimiento dedicado, en su centro histórico, a negociar el estatus de antiguos esclavos. Luego rindió homenaje al intelectual abolicionista y líder del club Juan Gualberto Gómez, de quien se había hecho amigo en una de las estadías de éste en Nueva York. "Puertorriqueños y Cubanos," Figueroa habló a la audiencia, "ahí tenemos ese Negro, esa inteligencia, el gran Cubano [Juan] Gualberto Gómez." Finalmente tomó la mano de Hanibal Castro, el "hijo de Colombia”, y solicitó otra ronda de aplausos por sus hermosas palabras antes de regresar a su asiento en medio de ovaciones. ${ }^{30}$

El Partido Revolucionario Cubano, tan inundado de la retórica de la neutralidad racial como estaba, fue una entidad en la que las visiones alternativas sobre raza e historia podían discutirse. El movimiento cubano revolucionario en Nueva York no era sólo lugar de debates sobre historia y raza entre cubanos. Era también un imán que atraía activistas de color de otras partes de la cuenca del Caribe, una entidad en la que podían articular sus propios reclamos de inclusión en narrativas nacionales. Colombianos, Dominicanos, y Puertor-

29. Asamblea extraordinaria en "Military Hall" 6 de octubre, 1895, SCRBC, Antillas

30. Sotero Figueroa. La verdad de la historia. San Juan, PR: Instituto de Cultura Puertorriqueña, 1977. Asamblea extraordinaria en "Military Hall," 6 de Octubre, 1895, SCRBC, Antillas. 
riqueños como Schomburg, Rosendo Rodríguez, Sotero Figueroa y Francisco Gonzalo Marín, quienes habían comenzado a formular sus propias historias alternativas sobre clase y raza en el movimiento liberal puertorriqueño de la década de 1880, formaron una alianza con activistas de similares opiniones en el Partido Cubano.

Tal fue el contexto de la carrera de Schomburg en la política nacionalista. La alianza con la causa cubana, para Schomburg y los demás puertorriqueños en el movimiento, era una alianza con el "ala izquierda" del movimiento cubano, es decir con los clubes artesanos y sus "ideas avanzadas" sobre libertad e igualdad social. Aun así, después de que Martí abandonara Nueva York dicho sector de izquierda fue progresivamente marginado del liderazgo del partido. A medida que Patria optó por una línea más y más conservadora, Sotero Figueroa y Rafael Serra comenzaron a publicar su propio periódico llamado Doctrina de Martí, defendiendo su visión racial y socialmente progresista de la causa revolucionaria como el verdadero legado de Martí. ${ }^{31}$ Hicieron de la memoria de Martí el rasero de su defensa de la política progresista de raza y clase en el movimiento. Parece que Schomburg era un aliado en esta causa. Justo antes de cerrar la sesión en Military Hall en octubre de 1895, cinco meses después de la muerte de Martí, el secretario Arturo Schomburg, quien diligentemente había escuchado discursos sobre clase, raza e historia tomando notas en su libreta, se levantó y solicitó "que los Antillanos respondieran a un viva á la memoria sagrada de nuestro querido Цosé Martí." Tal vez se trató de un saludo inocente al héroe nacionalista. Pero en el contexto de un Partido Revolucionario Cubano dividido, se trató probablemente de un intento por vincular el símbolo del mártir caído con las políticas radicales de clase y raza que tanto había permeado la oratoria de la noche. Este fue el único discurso registrado de Schomburg como nacionalista puertorriqueño. La multitud rugió un enfático “iviva!" antes de concluir la reunión. ${ }^{32}$

Las actas de las reuniones de Las Dos Antillas que Schomburg conservó revelan también parte de la desilusión que tanto él como otros comenzaron a sentir a medida que la guerra progresaba en Cuba y es que las expediciones a Puerto Rico, prometidas por la recientemente formada Sección Puerto Rico del Partido Cubano Revolucionario, no se materializaban. El 26 de julio de 1896, en una sesión conjunta de Las Dos Antillas y Borinquen, varios compañeros tomaron la palabra y propusieron, en un tono desesperado, una invasión inmediata de la isla más pequeña. Marcos Rosario, escribió Schomburg en el libro de actas, "suplicó a la Colonia que abandonaran la oratoria y pasasen a hacer efectivo lo que tanto habían prometido, hizo presente también la posesión de un Rifle." Otros oradores tomaron también la palabra y prometieron liberar a

31. Véase Serra, Ensayos polítcos. Tercera Serie (1899) and Serra, La República Posible. (Havana: Imprenta y Papelería de Rambla y Rouza, 1909).

32. Asamblea extraordinaria en "Military Hall” 6 de octubre, 1895. SCRBC, Antillas. 
Puerto Rico de España o morir en el intento. Schomburg tomó un inventario al momento en que los miembros del club anunciaban las armas que estaban dispuestos a donar a la causa. ${ }^{33}$

En este contexto surgieron dos divisiones relevantes en la comunidad exiliada en Nueva York. La primera acaeció entre los radicales de los clubes revolucionarios y los profesionales y mercaderes que incrementaban su control tanto del liderazgo del PRC y la Sección Puerto Rico del Partido Revolucionario Cubano En La Doctrina de Martí, Serra y Figueroa protestaron cuando un grupo de profesionales, sin consultar a los clubes, comenzaron a preparar el marco legal para una potencial república Cubana. Al mismo tiempo, una segunda fisura emergió entre el liderazgo puertorriqueño tras la maniobra del Presidente de la Sección Puerto Rico, Julio J. Henna, para separase de los cubanos, ya que él estaba en desacuerdo sobre si los fondos recolectados por el Partido deberían invertirse en expediciones a Puerto Rico. Henna comenzó un cabildeo ante los Estados Unidos para que Puerto Rico fuera incluido en sus planes de intervención en la guerra Hispano-Cubana. Para los separatistas puertorriqueños radicales, quienes albergaban esperanzas de republicanismo popular y reforma social, el apoyo continuado a la causa cubana, aun bajo Estrada Palma, era más preferible que negociar con el segregacionista y pro-inversionista gobierno de los Estados Unidos. En 1896 los clubes sostuvieron un voto de confianza conjunto a Estrada Palma, director de la delegación cubana en Washington. Poco tiempo después Figueroa renunció a su posición en el comité ejecutivo de la Sección Puerto Rico. "Veo con sentimiento", escribió, "que marchamos dando palos de ciego, sin unión ni cordialidad." ${ }^{34}$

En lugar de esperar para que la lucha se difundiera a Puerto Rico, unos trescientos exiliados puertorriqueños escogieron simplemente unirse al ejército Mambí en Cuba. ${ }^{35}$ Así por ejemplo, en marzo de 1896 Francisco Gonzalo Marín anunció su decisión de partir a Cuba, una decisión que para él tenía todo que ver con su dignidad y honor como hombre, que era su manera preferida de discutir cuestiones de igualdad social. "Tan llena de fuego y de eloquencia como siempre," Schomburg comentó en sus notas, Marín "nos calificó de soldados sin gloria, infecundos, y sin tener la satisfacción de ser un soldado que pelea por la desdichada Cuba y mi desgraciado Puerto Rico.” Posteriormente, como recordatorio de que las políticas raciales permeaban la cuestión de la

33. 26 de julio, 1896. SCRBC, Antillas.

34. Partido Revolucionario Cubano. Sección Puerto Rico. Memoria de los trabajos realizados: 1895 a 1898. (New York City: Imprenta A. W. Howes, [1898]) 198-200. Natal, Puerto Rico y la crisis de la guerra hispanoamericana, 87-120. Toledo Sotero Figueroa, 72-81. Carta de los Clubes Borinquen y Las Dos Antillas a Tomás Estrada Palma, Julio del 1896. SCRBC, Antillas. Toledo Sotero Figueroa, 80. Para el conflicto entre Figueroa y Enrique Trujillo véase la serie de artículos escrito por Figueroa, "Que calle la pasión y hable la sinceridad" en La Doctrina de Martí, empezando el 2 de octubre, 1896.

35. Natal, Puerto Rico y la crisis de la guerra hispanoamericana, 106. 
hombría y el sacrificio, el poeta rindió, en palabras de Schomburg, "igual y justo tributo al General Maceo" cuyas veintitrés heridas de batalla lo convertían en "el hombre que reivindica su raza." ${ }^{36}$ Es posible que Schomburg considerase seriamente seguir también el mismo camino pues posteriormente recordaba que sus amigos estaban "temerosos de que yo estuviera tan animado hasta el punto de ir a Cuba y perecer en las ciénagas miasmáticas." ${ }^{37}$ Pero él ya tenía una joven familia en Nueva York y, en cualquier caso, se veía a sí mismo principalmente como un intelectual y no como un soldado.

En lugar de esto, a medida que los clubes puertorriqueños comenzaron a desgranarse a fines de la década de 1890, Schomburg, tal como Serra y Figueroa, continuó su trabajo intelectual en Nueva York. Coleccionaba documentos, escribía y asistía a reuniones. Se dedicó a la revolución cubana pero nunca empuñó una arma. Mirando en el espejo resquebrajado del nacionalismo puertorriqueño, dos imágenes capturaron su mirada: el reflejo persistente de la izquierda cubana y las alianzas negras internacionales que crecían a su alrededor en Nueva York.

Raza e historia entre imperios: 1898 y el significado de la “integridad racial” en Nueva York y La Habana

La agenda social amparada por Doctrina de Martí, y movilizada en el ejército cubano revolucionario, estuvo inmediatamente amenazada por el gobierno de los Estados Unidos establecido en 1898. Los gobernadores militares estadounidenses y sus aliados cubanos aprobaron la enmienda Platt e impulsaron a la presidencia de la República a Estrada Palma, abiertamente anexionista y contrario al movimiento obrero. ${ }^{38} \mathrm{El}$ nuevo gobierno republicano desarmó al ejército Mambí, repartió puestos políticos entre antiguos partidarios españoles, se propuso "blanquear" la nación mediante la inmigración y la criminología, y comenzó a restaurar la economía de plantación. Oficiales estadounidenses buscaron arrebatarle el derecho al voto a los sectores populares mediante requisitos de propiedad y alfabetismo similares a los que estaban en vigor en el Sur de los Estados Unidos. Aun así, la extendida demanda popular del sufragio universal masculino (otorgado en las Antillas por España en 1894) y el éxito de la idea de que la ciudadanía total para todos los cubanos, expuesta por veteranos y activistas de la igualdad de derechos, era el legado necesario de la lucha por la independencia, llevaron a la Asamblea Constituyente a incluir el sufra-

36. 18 de marzo, 1896. SCRBC, Antillas.

37. Schomburg a Mr. John Clarke. 1 de mayo, 1936. SCRBC, Schomburg.

38. Louis A. Pérez, Jr. Cuba Between Empires 1878-1902. (Pittsburgh: University of Pittsburgh Press, 1983). 
gio universal masculino en la nueva constitución cubana. ${ }^{39}$ En contraste, tal como lo anotaba Schomburg en una carta al New York Times en 1903, las asambleas constitucionales de los estados Sureños en aquellos años "privaban a los negros del ejercicio legal de sus derechos políticos y naturales." ${ }^{40}$ En Cuba los dos partidos principales cortejaban a los líderes políticos de color, a los clubes de artesanos y a las Sociedades de color, al igual que a los votantes rasos, muchos de los cuales vivían cerca de gente blanca en una fuerza de trabajo rural multirracial. Los veteranos periodistas-activistas Rafael Serra y Juan Gualberto Gómez, y los veteranos militares de color Lino D’Ou, Evaristo Estenoz y Agustín Cebreco presentaron sus candidaturas y fueron elegidos a puestos políticos de orden nacional durante la primera década de la República. El Partido Liberal, en particular, se construyó como el heredero de las alianzas interraciales de la lucha por la independencia, movilizando veteranos para una corta rebelión que buscaba impugnar el fraude electoral orquestado por Estrada Palma en 1906. A pesar de la garantía de derechos de ciudadanía activa, las cuestiones de igualdad de derechos y el acceso justo a los recursos estaban muy lejos de ser solucionados en una sociedad alejada de la esclavitud por tan sólo unas cuantas décadas. Si bien ninguno de los partidos adoptó las lógicas raciales comunes entre los supremacistas blancos de los Estados Unidos, los líderes de ambos trataron de movilizar apoyo popular sin ceder en sus propios y atrincherados privilegios de clase y color. Tal como lo habían hecho en el PRC, periodistas de color denunciaron el aguijón de la discriminación en la Cuba Republicana, aun mientras participaban en las alianzas del nuevo sistema de partidos. Como un editorial en el periódico habanero La Discusión explicaba en 1907, existía una aguda contradicción entre la retórica oficial de la igualdad y la realidad social del racismo. Los negros en Cuba, se quejaba el editorial, "están sometidos á un régimen de desigualdad disimulada, de desigualdad hipócrita." 41

Semanas después de intervenir en el conflicto en Cuba, en 1898, los Estados Unidos invadieron Puerto Rico, con el estímulo y el apoyo de Henna y los líderes de las Sección Puerto Rico. Un angustiado Sotero Figueroa propuso que la comunidad puertorriqueña en el exilio se reorganizara y comenzara a tramar un levantamiento contra la ocupación militar de Cuba por los Estados Unidos. Pero esta sugerencia era profundamente fantasiosa. Partidas

39. Para la situación de los intelectuales de color en Cuba en el siglo XX véase Alejandra Bronfman, Measures of Equality: Social Science, Citizenship, and Race in Cuba, 1902-1940. (Chapel Hill: University of North Carolina Press, 2004).

40. A. A. Schomburg. "Union League Club’s Actions," carta al director del New York Times. 20 de diciembre, 1903.

41. "La nota del día de 6 de Agosto de 1907" in La Discusión, Havana, republicado en Serra. Para Blancos y Negros. ( Habana: Imprenta "El Score," 1907), 210. Rebecca J. Scott, Degrees of Freedom: Louisiana and Cuba after Slavery. (Cambridge, Mass.: Belknap Press of Harvard University Press, 2005). 
sediciosas en pueblos y villas de Puerto Rico aprovecharon la llegada de tropas para atacar a representantes y casas comerciales españolas, y los pobladores a menudo saludaban a las tropas marchantes con banderas estadounidenses izadas. Mientras tanto, importantes políticos puertorriqueños (incluyendo una facción liderada por el médico liberal negro José Celso Barbosa y con un fuerte apoyo de artesanos urbanos) cambiaron su enfoque en la negociación sobre las condiciones de la ciudadanía y autogobierno con España por uno en negociaciones similares con los Estados Unidos. En Puerto Rico, tal como en Cuba, los representantes de los Estados Unidos favorecían medidas para restringir la participación política de los puertorriqueños de color. Sin embargo, en 1904 la legislatura puertorriqueña estableció el sufragio universal masculino en las elecciones locales (aunque a los puertorriqueños, sin importar el color, no se les permitía votar por gobernador o presidente, o tener representación en el Congreso de los Estados Unidos). ${ }^{42}$

Los veteranos de Borinquen y Las Dos Antillas tomaron diferentes caminos ante estas nuevas circunstancias políticas. Marín había perecido tras dieciocho meses de combate en los campos cubanos. Figueroa se mudó a Cuba tras la guerra. Junto con José Dolores Poyo, tabaquero y líder de la colonia cubana del sur de la Florida, intentó trasplantar la alianza obrera progresista en cuestiones raciales, construida en los años del exilio, de regreso a la Cuba republicana. Además, confió en su amistad con Juan Gualberto Gómez, ahora político bien establecido del Partido Liberal, para asegurar y preservar un puesto gubernamental como impresor. Rafael Serra regresó a Cuba donde continuó su trabajo como periodista, educador y activista político, con vínculo al partido de Estrada Palma. Estrada Palma siempre había mantenido una relación cordial (quizás con un sabor de patrón y cliente) con La Liga, los clubes, y La Doctrina de Martí, cuando él vivía en Central Valley, Nueva York. En 1904, Serra fue elegido a la Cámara de Representantes. Muchos tipógrafos y tabaqueros en Nueva York, San Juan y Ponce buscaron una política de clase independiente, vinculada bien con el socialismo de la segunda internacional o bien con la defensa de trabajadores "americanos" ofrecida por la Federación Americana del Trabajo. A ellos se unió, durante la primera década del siglo XX, una fuerza laboral rural multirracial en crecimiento, parte de la industria del azúcar en rápida expansión por aquel entonces. Otros de los activistas e intelectuales artesanos puertorriqueños, apoyaban a Celso Barbosa, quien, como líder del Partido Republicano en Puerto Rico, se convirtió en el

42. Sección Puerto Rico. Memoria de los trabajos realizados. Picó, Fernando. 1898: La guerra después de la guerra. (Río Piedras: Ediciones Huracán, 2004). Para el "propósito de Figueroa de levantar un cuerpo aquí que peleé contra los americanos" véase la carta de J.A. Lanuza Letter a R.E. Betances. 21 de julio, 1898. Centro de Investigación Histórica, Universidad de Puerto Rico, Río Piedras. 
proponente principal de la Americanización y la admisión de Puerto Rico en condición de estado. ${ }^{43}$

Schomburg siguió un camino diferente. Tras la muerte de su mujer Elizabeth en 1900, dejó a sus hijos al cuidado de los familiares de su esposa en Virginia y Tennessee y él permaneció en Nueva York. En 1901 encontró trabajo como mensajero y oficinista para la firma Prior, Mellis y Harris. En 1902 volvió a contraer nupcias, nuevamente con una mujer negra del Sur de los Estados Unidos, Elizabeth Morrow Taylor de Carolina del Norte. ${ }^{44}$ Schomburg volvió a formar un hogar angloparlante, arraigado en las comunidades negras multiétnicas de Nueva York. Fuera de la familia, igualmente, Schomburg se dirigió cada vez más hacia los círculos sociales negros. En primer lugar entre sus nuevos amigos figuraba un periodista negro de Nueva York entrado en años llamado John Edward Bruce cuyo panafricanismo influenció profundamente en la cambiante visión de la raza que tenía Schomburg. Bruce, un liberto que había aprendido por sí mismo el oficio del periodismo, era contemporáneo y amigo de los tempranos pensadores panafricanos Alexander Crummell y Edward Blyden. A fines del siglo XIX, ayudó a sentar las bases de una ideología de solidaridad racial internacional entre la sociedad negra, una corriente intelectual que se movilizó inicialmente entre un círculo relativamente pequeño de intelectuales cosmopolitas y que fue posteriormente popularizado en Harlem por el orador callejero Hubert Harrison y el joven radical jamaiquino Marcus Garvey. Schomburg conoció a Bruce mediante sus vínculos con los masones, pero su amistad también debía mucho a los antiguos vínculos entre periodistas afroamericanos (especialmente T. Thomas Fortune, redactor del New York Age e íntimo compañero de Bruce) y la causa cubana. Para 1905, Bruce convenció a Schomburg de unirse al Sunday Men's Club, una sociedad literaria que se reunía en su apartamento de Yonkers. A medida que el mundo social y político del movimiento separatista puertorriqueño comenzaba a fragmentarse, tanto el ambiente familiar del club literario y social como la aguda política del separatismo racial militante llamaron la atención de Schomburg. ${ }^{45}$

Seguía atento a las actividades de sus viejos compañeros. En 1902, Schomburg le envió a Estrada Palma una carta felicitando su victoria. El mismo año, también dio señales de concurrir con la política de Celso Barbosa. Escribió al

43. Toledo, Sotero Figueroa. 100-101. De La Fuente, A Nation For All 60-67. Bronfman, Measures of Equality, 67-78. Negron Portillo, Mariano. Las turbas republicanas 1900-1904. (Río Piedras: Ediciones Huracán, 1990). Jiménez Román, "Un hombre (negro) del pueblo."

44. Con Elizabeth Morrow Taylor tuvo dos hijos, Reginald Stanfield y Nathaniel José. Con su tercera esposa tuvo a tres más, Fernando Alfonso, Dolores María y Carlos Plácido.

45. Para el panafricanismo a fines del siglo XIX, Gilroy, The Black Atlantic, 19-29, Anthony Appiah, In My Father's House: Africa in the Philosophy of Culture. (NY, Oxford: Oxford University Press, 1992), 3-46. Para contactos entre el movimiento cubano y T. Thomas Fortune véase, por ejemplo, "Gran noche de verano," Doctrina de Martí, 2 de octubre, 1896. Sobre Bruce, véase Des Verney Sinnette, Arthur A. Schomburg. 
New York Times objetando una propuesta de imponer restricciones migratorias a los puertorriqueños, expresando sus esperanzas de que éstos serían pronto recompensados por su "paciencia, trabajo, y utilidad durante la guerra" con "la feliz admisión de su isla en la hermandad de los estados." ${ }^{36}$ Pero el contexto de sus nuevos amigos y clubes tuvo un impacto importante en su política racial. Comenzó a adoptar un enfoque biológico a la unidad racial que su nuevo mentor predicaba, citando a Bruce en un artículo de 1905: "El Negro, que alguna vez esté en lo cierto, pero con razón o sin ella recordemos que el es hueso de nuestros huesos y carne de nuestra carne y que estamos indisolublemente ligados en la felicidad y en la tristeza, allí donde bajo el sol o el firmamento se encuentre alguno de nuestra raza." ${ }^{47}$ En el curso de las siguientes dos décadas Bruce y Schomburg se hicieron colaboradores cercanos, trabajando juntos para crear la Negro Society for Historical Research en 1911. Ambos se convirtieron además en partidarios fundamentales del movimiento de Garvey al final de la Primera Guerra Mundial, aunque Schomburg conservó cierta distancia no habiéndose unido nunca la United Negro Improvement Association de Garvey. Con todo, le ayudaba a Garvey con investigación histórica y traducciones. ${ }^{48}$

El creciente contacto social de Schomburg con Bruce y otros negros anglófonos evidentemente ayudó a dar nueva forma a sus ideas sobre la raza. Pese a ello, esta evolución debe entenderse en términos de su continua reflexión y vinculación con el experimento cubano, e incluso con el mundo de los artesanos intelectuales negros en Puerto Rico. En parte, este vínculo se concebía en términos casi imperiales. Como Blyden, Bruce y otros intelectuales negros en las capitales imperiales de París y Nueva York, Schomburg veía a los norteamericanos negros como más "avanzados" que sus contrapartes en África y el Caribe. Esta superioridad significaba que los negros de clase media estadounidenses deberían asumir el liderazgo en cualquier proyecto mundial de avance racial. En 1904, Schomburg sugirió, por ejemplo, que afronorteamericanos relativamente avanzados deberían difundir su superioridad moral y técnica a haitianos atrasados, tal como lo estaban haciendo entre las ignorantes masas negras del Sur. Escribió: “Tan sólo deseo que pudiera infundirle a Hayti graduados de la escuela técnica Booker T. Washington, quienes levantarían al pueblo hacia un amor ambicioso que incrementaría la riqueza material de la gente y del país." ${ }^{39}$

46. Carta de A. Schomburg a Tomás Estrada Palma,1902 in SCRBC, Schomburg. Arthur A. Schomburg, "Questions by a Porto Rican" New York Times. 9 de agosto, 1902. Sam Erman, "Meanings of Citizenship in the U.S. Empire: Puerto Rico, Isabel Gonzalez, and the Supreme Court, 1898 to 1905," Journal of American Ethnic History, 27, 4, (Summer 2008).

47. Guarionex (A.A. Schomburg). "Bruce Grit Honored." The Guardian. (Boston) October 7, 1905.

48. Des Verney Sinnette, Arthur Alfonso Schomburg, 126. James, Holding Aloft the Banner of Ethiopia, 211-213.

49. Arthur A. Schomburg. "Is Hayti Decadent?" The Unique Advertiser IV. Agosto, 1904. La mirada de Schomburg hacia el Caribe reflejaba por el prisma de la expansión estadounidense en 
En su mirada internacionalista, trasladarse del Caribe a los clubes y logias de clase media de Harlem era ascender en el mundo.

A pesar de esta visión general, los activistas negros en Estados Unidos veían a los veteranos de la lucha en Cuba con mucho respeto. A media que se acercaba hacia los círculos sociales negros, Schomburg permitía que sus nuevos conocidos lo recibieran como "caballero cubano refinado" y veterano del movimiento nacionalista. ${ }^{50}$ Intelectuales cubanos y aún puertorriqueños serían participantes cruciales en la hermandad internacional que él y Bruce proponían. Era posible imaginar tal alianza en tanto que, a medida que crecía la influencia de los Estados Unidos en el Caribe, Schomburg compartía con sus homólogos que regresaban a Cuba y aquellos que vivían bajo los Estados Unidos en Puerto Rico una cercana atención a las comparaciones entre el estatus de la gente de color en Cuba y en Norteamérica. Sus homólogos en las islas admiraban con frecuencia las instituciones sociales negras de los Estados Unidos, las mismas instituciones a las que Schomburg comenzó a unirse. Además, compartían con Schomburg las esperanzas de que una alianza entre ellos y la sociedad civil negra de Estados Unidos podría resultar mutuamente beneficiosa. En La Habana Rafael Serra (quien había vivido por más de una década tras la línea que separaba los colores en los Estados Unidos) dedicó considerable espacio en su periódico El Nuevo Criollo, y en la mayoría de su volumen de 1907 Para Blancos y Negros, a comentarios comparativos sobre la situación de los afrocubanos y los afronorteamericanos. En un artículo titulado "Los Negros Americanos", resumió su percepción de esta comparación. Con respecto a los Estados Unidos escribió: "se dice, con razón sobrada, que aquel país es el colmo de la más amarga preocupación contra la clase de color. Esto es cierto." Pero de algún modo, reflexionó, los negros norteamericanos se las habían arreglado para sobreponerse a esta amarga discriminación hasta sobrepasar los logros de los afrocubanos y de otras poblaciones negras del mundo. Puede que no tuvieran derechos electorales, pero en términos de riqueza, educación y poder político los negros norteamericanos, le parecía a Serra, le llevaban una gran distancia a los afrocubanos. Ellos, de alguna forma, "asombrosamente se desenvuelve[n] en los distintos ramos de la actividad humana." En Puerto Rico escritores negros, incluyendo más notablemente a Barbosa (quien había vivido en Nueva York y en Michigan), se enfrentaban a preguntas similares. ¿Ofrecían las políticas raciales de los Estados Unidos, incluyendo, por un lado, las leyes en contra de la miscegenación y la practica del linchamiento y, por el otro, la NAACP y Tuskeegee, ventajas

la región. Formuló sus impresiones sobre Haití, por ejemplo, mientras acompañaba a una expedición a Santo Domingo con una empresa minera estadounidense. Véase el manuscrito inédito de Schomburg acerca del viaje en SCRBC, Schomburg.

50. Véase nota 11. 
sobre las prácticas puertorriqueñas de harmonía racial oficial y prejuicio de casta no oficial? ${ }^{51}$

Serra presentó la comparación no solamente como una forma de criticar las relaciones de raza cubanas sino también con la esperanza de que el impresionante éxito negro norteamericano pudiera transformarse en un recurso para los movimientos o el avance raciales en las islas. Su visión del avance racial era predicada sobre la autoeducación, la elevación y las demostraciones públicas de virtud. El Nuevo Criollo imprimía artículos regulares sobre estadounidenses negros millonarios, doctores, bancos de ahorros, presentados no sólo como una inspiración para cubanos negros y mulatos (o como prueba de que las gentes de estirpe africana podían alcanzar grandeza como profesionales y negociantes), sino como una posible fuente de inversión que podría ser simpatizante de los esfuerzos afrocubanos. El editor del periódico estimaba la propiedad total de los norteamericanos negros en unos impresionantes \$335.000.000. Para atraer este capital, y cosechar los beneficios del éxito norteamericano, sin embargo, los cubanos tenían que cultivar las líneas apropiadas de solidaridad racial internacional. Así, a medida que los contemporáneos de Schomburg en Nueva York comenzaban a imaginar nuevas oportunidades de inversión y trabajo misional en atrasadas comunidades negras extranjeras, el internacionalismo racial emergió con un aspecto ligeramente diferente en el otro extremo de la cadena alimenticia colonial. ${ }^{52}$ Asegurar una alianza con activistas y donantes negros pudo haber sido parte del objetivo del viaje que Rafael Serra y Evaristo Estenoz (un periodista y político de color asociado con el Partido Liberal) hicieron a Nueva York en 1905. Estenoz aparentemente usó la promesa de asistencia financiera y técnica de norteamericanos negros como parta de campañas políticas en Cuba. Este tipo de visitas a amigos y aliados en Nueva York para la recaudación de fondos era un viejo truco para los veteranos del Partido Revolucionario Cubano, si bien ahora sus alianzas eran alianzas de raza. ${ }^{53}$

51. Véase Serra Montalvo, Para Blancos y Negros, 135, 184-187. Planas y Hernández, Emilio. El Problema. (Matanzas: La Pluma de Oro, 1905) favorecía la formación de colegios para Cubanos de color, basado en la filantropía de los cubanos blancos, siguiendo el modelo de Tuskeegee. Véase los escritos sobre Booker T. Washington del puertorriqueño de color Luis Felipe Dessús, Flores Y Balas (Estados De Alma). (Guayama P.R.: Tip. Union guayamesa, 1916).

52. La iglesia AME, por ejemplo, envió misionarios a Santo Domingo, Haití, y Cuba, formando parte de una misión más amplia de americanización por medio del protestantismo. La iglesia AME también trató de fomentar una identidad racial independiente entre las poblaciones de color en el Caribe. Jualynne Dodson. "Encounters in the African Atlantic World: The African Methodist Episcopal Church in Cuba," in Between Race and Empire, ed. Brock and Castañeda, 85-103. Kevin Gaines “Black Americans' Racial Uplift as a 'Civilizing Mission': Pauline Hopkins on Race and Imperialism," in Cultures of United States Imperialism, ed. Amy Kaplan and Donald E. Pease (Durham, NC: Duke University Press, 1993), 433-455. Appiah, In my Father's House, $3-46$.

53. En un fragmento de sus papeles John Bruce (c. 1910) se queja de que Estenoz decía que tenía amplias conexiones con negros estadounidenses, y prometía a sus seguidores que podía 
Los cubanos estaban concentrados en construir vínculos con gente negra norteamericana económicamente fuerte para asegurar inversión o capital humano, los norteamericanos buscaban asumir el rol de líderes raciales internacionales estableciendo relaciones semicoloniales con sus hermanos extranjeros, y Schomburg comenzó a verse a sí mismo como el corresponsal y traductor que podría hacer realidad esta alianza internacional. El debut de Schomburg como secretario del Men's Club fue una cena organizada por el en 1905 para honrar el aniversario de la entrada de John Bruce al periodismo, y entre sus invitados estaban Rafael Serra, entonces miembro de la Cámara de Representante cubana; Tomás Carrión, un periodista y maestro de escuela de orígenes artesanos y ascendencia africana, que era entonces miembro de la Cámara de Delegados de Puerto Rico, y Edward Blyden, el embajador de Liberia en Francia. ${ }^{54}$ Este núcleo de amigos y colegas negros internacionales, junto con Mojoli Agbebi de Nigeria y Evaristo Estenoz de Cuba, se convirtió en el grupo de miembros corresponsales de la Negro Society for Historical Research en 1911. Otro miembro era Pedro Timothee, un maestro de escuela y periodista en San Juan, de origines artesanos y ascendencia africana. Timothee era miembro activo de la Federación Regional de Trabajo que apoyaba a Barbosa, así como miembro de la cámara baja de delegados. La misión de la sociedad era estimular "la recolección desde todas partes del mundo de libros y documentos tocantes al Negro," y también agrupar "en una sola sociedad por vez primera y cooperativamente académicos africanos, de las Indias Occidentales y afroamericanos." La sociedad también aseguraba tener miembros en Boca del Toro, Costa Rica y Limón Panamá, plazas de clubes revolucionarios cubanos en la década de 1890 y, posteriormente, de extenso activismo pro-Garvey. ${ }^{55}$

No está claro hasta qué punto la inclusión de Agbebi, Blyden, Estenoz, Carrión y Timothee en las listas de miembros reflejaba un contacto frecuente y sustancial con los corresponsales extranjeros. Aun así, la aspiración a esta red internacional de corresponsales refleja claramente las formas en que Schomburg se ubicó dentro de los clubes sociales e intelectuales de habla inglesa y panafricanistas. Al mismo tiempo, las actividades de colegas en Cuba, particularmente Estenoz, jugaron un papel importante en su evolución política. Estenoz hizo parte de la rebelión de veteranos revolucionarios dirigida por José

conseguir inversiones y contribuciones por medio de ellas. Otro habla de un miembro "prominente" de la logia de los Odd Fellows, una orden fraternal afroamericana en la cual participaban muchos cubanos de color, que hablaba de miles de dólares en inversiones de parte de negros americanos para proyectos en Cuba. SCRBC, Bruce.

54. Véase Guarionex (Schomburg), "Bruce Grit Honored" y el programa de la cena en honor a Bruce, September 28, 1905 y carta de Edward Blyden a Bruce, desde Paris. 19 de agostoa, 1905. Ambos en SCRBC, Bruce.

55. A.A. Schomburg, "The Negro Dig's Up His Past." in The New Negro: An Interpretation, ed. Locke, 236. Sobre Timothee y la FLT véase "Bulletin of the Department of Labor," Volume VI. Washington: Government Printing Office, 1901. 
Miguel Gómez en 1906, la cual reclamó el legado de la lucha independentista, incluyendo el proyecto de la fraternidad racial. Ahora bien, hacia 1908, en desafecto con Gómez, abandonó el Partido Liberal para asumir el liderazgo en un pequeño movimiento independiente de veteranos negros y mulatos. Estenoz y sus seguidores denunciaron las políticas migratorias racistas, cabildearon por una educación pública mejorada, y demandaron una distribución más equitativa de los empleos públicos. Y en su propuesta más controversial, sugirieron que la organización de hombres de color era necesaria para forzar al sistema cubano de partidos a compartir recursos estatales más equitativamente. El gobierno cubano (controlado por los liberales) declaró ilegal el Partido sobre la base de que la organización racial independiente era contraria a la tradición cubana de unidad racial. Estenoz se trasladó a Oriente y comenzó a organizar campesinos desplazados (incluyendo algunos blancos) para la campaña electoral de 1912 y eventualmente anunció su propia rebelión armada. ${ }^{56}$

Schomburg siguió estos eventos desde lejos. Estenoz fundó el Partido Independiente de Color (PIC) en 1909. Un año más tarde, Schomburg envió un artículo que apareció en el periódico del partido, Previsión. ${ }^{57}$ En 1912 llevó el mensaje de Estenoz, posiblemente obtenido de números de Previsión, a una audiencia negra norteamericana. En un perfil del general en The Crisis, Schomburg replicó la aseveración de Estenoz según la cual el PIC era un movimiento de 60.000 personas con clubes germinando como "hongos" por toda Cuba. Además, aceptó la pretensión de Estenoz de hablar por los cubanos negros en general. Aunque los registros históricos parecen mostrar que la mayoría de votantes de color en Cuba no estaban convencidos del llamado a un partido basado en la raza, Schomburg se refería al PIC como "los negros de Cuba" que "entendían que los cubanos blancos habían determinado que ellos no deberían tener ninguna representación excepto aquella que les fuese concedida como caridad." El artículo expresa las esperanzas perdidas de forjar alianzas con "los blancos" fundamentadas en los partidos en el contexto de una ley electoral que Schomburg comparaba con el caso Dred Scott. "Muchos cubanos negros maldijeron el surgimiento de la República," escribió. "A los negros se les recibió en los tiempos de penurias, durante los días de la revolución, pero en los tiempos de paz y de emigración blanca son privados de posiciones, condenados al ostracismo y convertidos en parias políticos. El negro ha hecho mucho por Cuba. Cuba no ha hecho nada por el negro." Con todo, Schomburg percibía el levantamiento como consistente con los ideales originales del Partido Revolucionario Cubano, ideas que atribuía aún a la figura de Martí. "[C]omo mi amigo, el difunto José Martí, el apóstol de la libertad cubana, dijo," concluyó, “En tanto

56. Scott, Degrees of Freedom, 22-252.

57. A. A. Schomburg. "La historia verdadera de la Insurección de los esclavos bajo de la Cabecilla de Juan Buddhoe, quien es aún venerado por sus compatriotas." Prevision, 10 de febrero, 1910. 
haya siquiera una injusticia que reparar en Cuba, la redención revolucionaria no habrá completado su obra." 58

En 1912 Schomburg podía comprender el proyecto de Estenoz tanto en términos de sus propias ideas de nacionalismo racial como en términos de la política racial de Las Dos Antillas, como un esfuerzo para forzar la finalización de la lucha revolucionaria cubana. Tan sólo un año después, en un discurso titulado Integridad racial y pronunciado ante una audiencia de maestros negros, Schomburg hizo una de sus más claras declaraciones de separatismo racial, aparentemente rechazando la posibilidad de forjar alianzas cruzando las fronteras raciales. Además de unos cuantos "amigos blancos sinceros y solidarios que [han] peleado y batallado con nosotros," le dijo a su audiencia, los blancos habían demostrado ser aliados poco fiables. Es posible que estuviera reflexionando sobre el Partido Republicano en los Estados Unidos, que a pesar de sus tradiciones abolicionistas, había colaborado con los Demócratas en el establecimiento de Jim Crow. Es posible que también tuviera en mente a José Miguel Gómez, el presidente cubano que cultivaba y disfrutaba de un amplio apoyo de votantes y políticos de color, pero que clasificó la rebelión de Estenoz como una guerra "racista" desatando un espeluznante episodio de terror contra la gente de color en Oriente. A los ojos de Schomburg, por lo menos en el año 1913, el proyecto nacionalista había fracasado y la única respuesta era que la gente de color construyera vínculos de "patriotismo racial." En particular, explicaba, los negros deberían aspirar a formar alianzas políticas, económicas y culturales con gente negra de otros países para así forjar una coalición racial internacional. "El Negro debe esforzarse por seguir el buen ejemplo de los judíos," argumentaba, "quienes sin ser una nación en la práctica, viven en teoría como una nación de los más potentes intelectos." Admiraba lo que percibía como la inamovible unidad de los judíos aun tras siglos de exilio. "[E]llos se aferran a sus costumbres y tradiciones, sin importar si viven en Tombuktu o en el más alto de los picos de las montañas andinas.” Los hijos de África, como lo hijos de Israel, argüía, deben "agruparse y sostener la máxima de 'la unidad hace la fuerza.” Los negros, sentía Schomburg, haciendo uso del concepto judío de "Diáspora," deberían emular esta unidad internacional o de lo contrario se perderían en las vicisitudes de la política nacional aislada. ${ }^{59}$

No hay forma pues de confundir el agudo contraste entre esta ideología racial separatista e internacionalista y la unidad racial y fraternidad nacionalista

58. Arthur A. Schomburg "General Evaristo Estenoz." The Crisis. October, 1912. 144. Véase David J. Hellwig "The African American Press and United States Involvement in Cuba, 1902 1912." in Between Race and Empire: African Americans and Cubans before the Cuban Revolution. ed. Lisa Brock and Digna Castañeda Fuertes. (Philadelphia: Temple University Press, 1998) $70-84$.

59. Arthur.A. Schomburg. "Racial Integrity: A Plea for the Establishment of a Chair of Negro History in our Schools and Colleges, etc. Address delivered at the Teachers' Summer class at the Cheyney Institute, July 1913." (Baltimore: Black Classic Press, 1979) p. 6-7. 
propugnadas por Martí, aun cuando era apropiada y reformulada por hombres como Serra, Figueroa y Juan Gualberto Gómez. Schomburg pertenecía a un segmento del movimiento independentista puertorriqueño que depositaba sus esperanzas de igualdad racial y reforma social en el proyecto de liberación nacional en Cuba. La muerte de Serra deshizo su último vínculo con compañeros que continuaban buscando margen de maniobra dentro de la política de partidos multirracial. Parece que el desafecto de Estenoz y la represión gubernamental que siguió ayudó a convencerlo de la fragilidad de las alianzas multirraciales, mientras que sus nuevas amistades entre panafricanistas en Nueva York le ofrecían otro tipo de alianza.

Schomburg comenzó a verse a sí mismo como un intelectual, un coleccionista, al servicio de una red racial internacional. "Necesitamos una colección o lista de libros escritos por nuestros hombres y mujeres," le dijo a su audiencia en 1913. "Necesitamos que el historiador y el filósofo nos entreguen, con una pluma mordaz, la historia de nuestros ancestros y permitir que nuestra alma y nuestro cuerpo, con luz fosforescente, iluminen el abismo que nos separa." ${ }^{\prime 60}$ Coleccionar, pensaba, y documentar las contribuciones negras a la civilización mundial mediante la ciencia de la historia, inspiraría el patriotismo racial necesario para construir una alianza negra internacional cruzando las divisiones creadas por las fronteras nacionales y el provincialismo. Esta sensibilidad histórica, si bien aplicada recientemente a la causa de la unidad racial internacional, tenía sus raíces en los días de Schomburg entre intelectuales nacionalistas puertorriqueños y cubanos. La historia en general y el coleccionismo en particular habían sido, en efecto, algo así como una manía entre los nacionalistas emigrados en Nueva York. Era como si el colonialismo y el desplazamiento produjeran una desazón sobre la pertenencia que sólo podía disiparse con listas de libros, esbozos biográficos y otros testamentos de los logros de los progenitores nacionales. Sotero Figueroa publicó un volumen de ensayos biográficos "de los que más han contribuido al progreso de Puerto Rico." Martí coleccionaba poesía, Flor Baerga coleccionaba libros y documentos, José González Font, antiguo jefe de Schomburg, coleccionaba y reeditaba recortes de periódico relacionados con Puerto Rico. ${ }^{61}$ Buscaban construir un patrimonio puertorriqueño, escribiendo una historia para inspirar unidad y concientizar a los miembros de la comunidad nacional. Y esperaban establecer una conexión entre esa comunidad y la narrativa trascendente del progreso humano que dominaba su percepción de la modernidad. El colonialismo había

60. Schomburg, "Racial Integrity, 7, 18.

61. Sotero Figueroa. Ensayo biográfico de los que más han contribuido al progreso de Puerto Rico. (Río Piedras: Editorial Coquí, 1973) José González Font, Escritos sobre Puerto Rico. (Barcelona: José González Font, 1903) 188-189. Había además varios trabajos sobre proyectos históricos establecidos por los tabaqueros en Puerto Rico, y Alejandro Tapia y Rivera fundaron la Biblioteca Histórica in these years. Estoy en deuda con un juez anónimo que hizo referencia a ello en una versión anterior de este documento por atraer mi atención. 
separado a los puertorriqueños de su legítima participación en esta narrativa y mediante el coleccionismo histórico estos intelectuales se proponía constituir una identidad nacional. ${ }^{62}$

Si anhelar por un sentimiento de pertenencia moderno produjo un impaciente florecimiento intelectual entre nacionalistas puertorriqueños, la carga añadida de exclusión racial doblaba la necesidad de Schomburg de establecer un lugar para sí mismo en la historia. Como hemos visto, las conversaciones sobre historia al interior de los movimientos cubano y puertorriqueño estaban a menudo cargadas con preguntas sobre el papel de los artesanos y hombres de color en la historia nacional, así como sobre la marcha universal de la civilización. Sin raíces históricas fidedignas, Schomburg dijo a su audiencia en 1913, "A menudo sentimos que muchas cosas a nuestro alrededor están retorcidas y alienadas." ${ }^{63}$ La respuesta, concluyó, era construir un archivo, un testimonio científico permanente del lugar prominente de la valentía y sabiduría negras en la cultura Occidental. De nuevo, este tipo de esfuerzo había sido común al interior del mundo de los clubes artesanos y del activismo independentista. En el contexto del debate sobre cómo la diversidad racial y de clase deberían dar forma a esa identidad nacional, artesanos en Las Dos Antillas y Borinquen (muchos o la mayoría de los cuales tenían ancestros africanos) se esforzaron especialmente para asegurarse de que fueran incluidos en las historias nacionales en términos satisfactorios. Los intelectuales de color en el movimiento puertorriqueño y cubano participaron en proyectos para coleccionar y publicar historias de figuras prominentes de color. Ya trasladada su imprenta a La Habana en 1900, Sotero Figueroa tipografió y publicó el libro Rectificaciones de Juan Felipe Risquet sobre la verdadera historia de los cubanos de color en el movimiento de independencia. Como anexo al libro publicaron una lista de personas de color notables de Puerto Rico, Estados Unidos, Francia, Rusia, Venezuela, y la África, un precursor directo de los trabajos intelectuales de Schomburg. ${ }^{64}$ Pero en la primera década del siglo veinte Schomburg migró de la periferia hispánica hacia el lugar más poderoso y prestigioso del mundo negro: Harlem. Y esta migración al centro lo ubicó en una posición única para ejercer su coleccionismo panafricanista.

Schomburg halló un lugar como ciudadano de segunda clase en el centro

62. Figueroa "La Verdad de la Historia" en Edgardo Meléndez. Puerto Rico en Patria (Santo Domingo, D.R.: Editorial Taller, 1996) 156-181.

63. Schomburg., Racial Integrity, 5.

64. Risquet, Juan Felipe. Rectificaciones: La cuestión político-social en la isla de Cuba. (La Habana: Tip. "América," 1900). 156-169. También es interesante como proyecto de revindicación histórica la colección de biografías de hombres de color en el movimiento separatista, Domiñguez, Teofílo. Figuras y figuritas: Ensayos biográficos. (Tampa: Impr. Lafayette Street 105, 1899). La copia que aún existe en la SSRBC tiene la inscripción, "Amigo A. Shumburg recibe este débil presente en prueba de afecto y consideración. José M. Rodriguez. New York, Abril 4/10." Posiblemente éste fue el Joseph Rodríguez que figura en el censo federal de EUA como cubano negro, casado con una mujer afroamericana, residente en Nueva York en 1910. 
del nuevo imperio, para refutar la mitología de la supremacía blanca que cubría al proyecto imperial. Los mismos barcos de vapor que habían llevado trabajadores migrantes de las Indias Occidentales a América Latina, que habían trasladado revolucionarios cubanos y puertorriqueños y sus cartas de puerto en puerto, barcos construidos con recursos financieros de firmas de Wall Street y protegidos por los Marines de los Estados Unidos, cargaban también la preciosa mercancía de Schomburg constituida por papeles e información. Su oficina en la sala de correo de Banker's Trust Co., la firma de Wall Street donde trabajó de 1906 a 1929, le permitía conducir con facilidad su correspondencia con negociantes de libros extranjeros, masones y amigos. Robó tiempo de su trabajo para escribir una multitud de cartas a negociantes y amigos en el extranjero solicitando ayuda para localizar bibliografías, libros o documentos. Se quejó con Bruce, en una carta al parecer escrita mientras trabajaba en 1912: "While am writing the boss of the joint ... is fussin' because I keep pegging away on the writing side of life," es decir, se quejaba su jefe de que Schomburg solía dedicarse a sus emprendimientos intelectuales durante sus horas de trabajo. ${ }^{65}$ Mientras su jefe se quejaba, Schomburg armaba su archivo, canalizando libros y documentos desde sus redes de amigos en la periferia de la civilización negra hasta su centro de operaciones en Nueva York.

\section{Arthur A. Schomburg, masón: movilidad de clase y asimilación negra después de 1898.}

La comunidad negra internacional que dio forma a las migraciones políticas e intelectuales de Schomburg después de 1898 no existía exclusivamente en sus pilas de libros y documentos, en su imaginación o en su correspondencia con Blyden, Bruce, Timothee y Estenoz. Podía verse cada día en las calles de Harlem. Entre 1900 y 1930, cuarenta mil inmigrantes negros llegaron a la ciudad de Nueva York, asentándose en el uptown junto con las decenas de miles de migrantes negros del Sur de los Estados Unidos y las comunidades negras más antiguas de Nueva York que se reasentaron en Harlem desde enclaves más tempranos en Greenwich Village, el Tenderloin y San Juan Hill. Más tarde en aquel siglo Harlem se convertiría en metáfora de una identidad negra explícitamente norteamericana, pero cuando la familia Schomburg se mudó allí en 1907 sureños negros vivían en las mismas cuadras, y a menudo en las mismas casas como inquilinos junto con indianos occidentales y haitianos. "Pequeñas isletas de sueños tropicales en lenguas extranjeras," llamaba Langston Hughes a estos foráneos, los ingredientes sabrosos del "crisol Harlem." ${ }^{66}$ Sobre su llegada a Nueva York en 1917, Jesús Colón recordaba: "En aquellos días los pocos

65. Carta de Schomburg a Bruce, 21 de marzo, 1912. SCRBC, Bruce.

66. Langston Hughes, "My Early Days in Harlem" in Harlem, A Community in Transition. ed. John Henrik Clarke (New York: Citadel Press, 1964), 64. 
puertorriqueños que había vivían en el corazón del barrio negro junto con la gente negra en los mismo edificios." ${ }^{37}$ Los censos muestran que es más acertado decir que entre 1880 y 1920, los puertorriqueños y cubanos de color, incluyendo todos los líderes y muchos de los miembros de La Liga, Las Dos Antilla y Borinquen, vivían junto a gente negra de habla inglesa. Bernardo Vega, en otra crónica de la temprana comunidad puertorriqueña en Nueva York, describió incidentes impresionantes de violencia contra obreros puertorriqueños que pretendían asentar sus familias y comunidades racialmente integradas en barrios blancos. Anotó que "no pocos paisanos negros" incluyendo a Schomburg, se mudaron hacia "el barrio negro norteamericano." ${ }^{68}$ De hecho, cuando perdió a su segunda esposa, Schomburg envió a sus hijos con sus abuelos maternos y se trasladó a un apartamento en la calle 115 Oeste, en un edificio poblado de indianos occidentales y norteamericanos negros. Vivió con Raymond Rothchild, un camarada de Las Dos Antillas. Rothchild, como Schomburg, había nacido en Puerto Rico, de padres provenientes de las Indias Occidentales danesas, y trabajaba de conserje en una universidad (probablemente la Universidad de Columbia). Sin embargo, Schomburg después se fue de Harlem. Después de casarse de nuevo, se mudó a Bedford Stuyvesant en Brooklyn, donde su familia vivía en un área que fue predominantemente blanca hasta su muerte en $1938 .{ }^{69}$

Más importantes que los lugares donde vivió son aquellos en los cuales socializó. Los patrones de vivienda eran guiados tanto por estructuras de segregación como por elección. Si bien la mayoría de los puertorriqueños de color compartían espacios con afroamericanos antes de 1920, Schomburg, aparentemente sólo entre los artesanos veteranos del Partido Revolucionario Cubano, se unió a clubes y hermandades negras de clase media como el Sunday Men's Club y, el más importante de todos, los Masones de Prince Hall, también conocido como Masones negros. Allí persiguió sus pronunciadas ambiciones de convertirse en un intelectual reconocido, y allí sus afinidades con la demás gente negra entre la que vivía fueron expresadas explícitamente en términos de internacionalismo racial. Aparte de su vida familiar, la masonería fue el marco institucional principal que organizaba sus migraciones sociales, políticas e intelectuales hacia el interior del Harlem y Brooklyn negros, incluso cuando ya no vivía allí. Si bien no hay duda de que su atracción por estas instituciones estaba relacionada con las ideas cambiantes sobre la raza que caracterizaban a Schomburg (y posiblemente con su herencia de las Indias Occidentales), su

67. Colon, A Puerto Rican in New York and Other Sketches. (New York: Mainstream Publishers, 1961). 44.

68. Andreu Iglesias. Memorias de Bernardo Vega,30-31.

69. Censo Federal de los Estados Unidos, 1910, 1920, 1930. Consultado en ancestry.com. Rothchild aparece en la lista de socios en SCRBS, Antillas. 
inserción en la masonería negra también estaba fundamentalmente atada a sus nociones de clase.

Con todo, este traslado inusual hacia la masonería negra siguió un sendero iluminado por los fundadores de su logia, un grupo de cigarreros de ascendencia africana que habían migrado de Cuba a Nueva York décadas atrás. En junio de 1880 Manuel Coronado, Sixto Pozo, Abraham Seino y Lafayete Marcus fundaron Sol de Cuba en Brooklyn. No se unieron a los grupos masones cubanos que ya existían en Nueva York, tramitando en cambio su afiliación a los Masones de Prince Hall, una institución integrada y administrada por afroamericanos y de la cual existían ya miembros iniciados. ${ }^{70}$

Que escogieran unirse a los Masones de Prince Hall requiere una explicación. La logia masónica existente en Nueva York no era de ningún modo abiertamente segregacionista. Tan sólo unos años antes, en 1878, un médico cubano llamado Ramón Ylla y un grupo de cigarreros de Manhattan fundaron la Logia Carlos Manuel de Céspedes, en honor del fundador y primer líder simbólico de la insurrección cubana. Dueño de una plantación, Céspedes había emancipado a sus esclavos de manera que pudieran pelear por la causa de una Cuba libre. Era por tanto un símbolo del vínculo entre el proyecto de independencia y el proyecto de abolición. La logia se adhería a la jerarquía de la Orden Caballeros de la Luz, fundada unos años antes por cigarreros cubanos en Filadelfia. ${ }^{71}$ Una "liturgia" de 1879 publicada por los Caballeros de la Luz expresa un compromiso retórico no sólo con la abolición sino también con el proyecto de igualdad racial y social. Raza y clase, instruía el documento, no serían tomados en consideración al examinar a potenciales hermanos. El Patriarca de la logia debía hacer cumplir esta regla cada vez que se formaba un nuevo comité de membresía, y debía "aconsejar" a los nuevos comités para "que nuestra Orden reconozca la igualdad de derechos y responsabilidad de todos los hombres." En cada reunión el Patriarca levantaba un objeto ritual y le decía a los hermanos que éste representaba la igualdad de todos los hombres, blancos y negros, ricos y pobres. Luego pronunciaba que el aprendizaje, la ciencia y la moralidad abolirían gradualmente todas las formas de prejuicio

70. "Petition for a warrant for a new lodge to be named 'Sol de Cuba' submitted to "the M.W. Grand Master of the H.F. of F.A.M. for the state of New York," 26 de junio, 1880. Harry A. Williamson Papers (SCRBC, Williamson). Véase Torres-Cuevas "Los cuerpos masónicos Cubanos durante el siglo XIX” and Manuel Hernández González. "La Orden Cubana de los Caballeros de la Luz en el exilio norteamericano," ambos en Masonería Española en América (Zaragoza, Spain. 1993).

“The History of Prince Hall Lodge No. 38" en el "Souvenir Program-75th Anniversary," (New York: November 4, 1956). SCRBC, Williamson.

71. "Libro de Actas- Gran Logia Luz de Caballero." 11 de abril, 1878. Pennsylvania Historical Society, Philadelphia, PA. Logia Luz de Caballero Manuscript Collection. (PHA, Logia Luz). 
social y que "toda desigualdad que no esté basada en méritos está en contra de la justicia." ${ }^{72}$

Si bien los integrantes de las logias de los Caballeros de la Luz parecían absorber los mensajes más progresivos del movimiento de independencia, lo hacían en un momento en el que el movimiento se veía fracturado por divisiones de raza y clase. En 1878 la insurrección titubeó en Cuba. Los líderes blancos se rindieron a España, en gran medida porque temían el creciente poder de sus aliados negros y mulatos. Los líderes negros y mulatos, como el General Antonio Maceo, junto con algunos aliados blancos, rehusaron aceptar la tregua y regresaron a la batalla en la Guerra Chiquita durante 1879 y 1880 . Las tensiones sobre la guerra y su política racial eran evidentes en las actividades de las logias exiliadas. Un aspirante a la logia en Filadelfia, Manuel Suárez, renunció a su candidatura en 1879 para protestar contra la declaración de "fraternidad universal" en los ritos de la logia. La Logia Carlos Manuel de Céspedes de Nueva York cambió su nombre por Logia El Progreso, tomando distancia del símbolo del nacionalismo y la abolición cubanas. Por esta razón, los cigarreros de Brooklyn que formaron su propia logia en 1880 pudieron haber tenido buenas razones para esperar una tibia bienvenida, no un segregacionismo oficial, en la Logia El Progreso. ${ }^{73}$

Aun más, un compromiso retórico con la igualdad racial y de clase no significaba necesariamente que hombres de color de la clase trabajadora pudieran en realidad esperar ser aceptados o tratados con igualdad. Como aprendieron negros y mulatos participantes en la lucha en Cuba, los aliados blancos a menudo les exigían mucho más en cuanto a cualidades de "mérito" aparentemente neutrales. La supuesta falta de civilización, aprendizaje o moralidad podía usarse para excluir individuos de posiciones de prestigio. ${ }^{74}$ Mientras el movimiento de independencia en Cuba se fracturaba por temores blancos de insurgencia negra, los miembros de los Caballeros de la Luz en Filadelfia estaban en desacuerdo sobre cómo ocuparse de los trabajadores de tabaco, blancos y negros, que deseaban unirse. Algunos hermanos propusieron usar fondos de la logia para apoyar clases nocturnas para la instrucción y elevación intelectual de los emigrantes más pobres. Esto resonaba con los casinos o clubes artesanos y los proyectos de educación popular anarquistas vigentes en Cuba en aquel tiempo. También se asemejaba instituciones que intelectuales cubanos de color, notablemente Rafael Serra y Juan Gualberto Gómez, crearon en aquellos años para elevar e incorporar la creciente clase de libertos y libertas. Los Caballeros de la Luz, sin embargo, aun dirigidos por propietarios de fábricas, rechazaron la propuesta priorizando una logia más excluyente y actos individuales de cari-

72. "Liturgia Orden Caballeros de la Luz" 1879. PHA, Logia Luz.

73. "Libro de Actas," 9 de febrero, 1879; 7 de marzo, 1879. PHA, Logia Luz. Ferrer, Insurgent Cuba. 70-89.

74. Ferrer, Insurgent Cuba. 170-194. 
dad con los menos afortunados. Según un miembro, ellos se opusieron a los esfuerzos por trasformar la logia en "una mesalina que se ocupaba en recoger hijos de todas clases y todos colores." ${ }^{75}$ La palabra mesalina tiene aquí el significado no únicamente de una mujer disoluta, sino específicamente de una mujer de alta sociedad que se prostituye para el beneficio de clientes de una clase inferior.

Es fácil ver cómo la atracción de las logias controladas por sus empleadores pudiera haber atenuado este contexto para muchos cubanos exiliados de la clase obrera. Tabaqueros cubanos, cada vez mas influenciados por el anarquismo así como por ideas liberales y masónicas, buscaron en cambio crear instituciones de solidaridad de clase y educación popular. Al mismo tiempo Juan Gualberto Gómez y otros comenzaron a crear sociedades de color en Cuba, organizaciones independientes lideradas por hombres de color y dedicadas a la educación y el elevamiento así como a la defensa de los derechos civiles. Esto puede explicar por qué los fundadores de Sol de Cuba, la logia de Schomburg, decidieron crear su propia logia en lugar de buscar entrada a Caballeros de la Luz. En efecto, muchos de los miembros originales de Sol de Cuba participaron más tarde en La Liga de Serra y otras sociedades de color afiliadas con el Partido Revolucionario Cubano. Para expresar reivindicaciones de ciudadanía completa o para vindicar la identidad negra dentro del más amplio ideario masónico de "progreso" universal, estos cigarreros de ascendencia africana crearon un espacio social independiente que ellos mismos podían liderar y moldear según sus objetivos.

Para lograrlo salieron a la búsqueda del apoyo institucional de los afroamericanos angloparlantes entre los Masones de Prince Hall. Si bien la creación de una logia negra separada reflejaba una tendencia general hacia la organización independiente en el contexto cubano, esto debe también por tanto entenderse en el contexto de un encuentro en la diáspora, fenómeno particular de los emigrados de color en Nueva York dado que cuando salieron de las fábricas de cigarros y los clubes sociales de inmigrantes que los unían mutuamente como cubanos y tabaqueros, estos hombres vivieron en una ciudad marcada por una línea que separaba los colores. En otras palabras, cualquiera que fuera el estado de sus alianzas en el interior de las fábricas y clubes de la comunidad de migrantes, los latinos de color de Nueva York se separaban de los latinos blancos al regresar a sus hogares. Allí disfrutaban de un contacto social considerable con personas que hablaban inglés. Este contacto residencial y social entre cubanos negros y afroamericanos ayuda a explicar cómo Marcus y Coronado establecieron sus primeros contactos con los Masones de Prince Hall. Es posible que tuvieran parientes políticos y vecinos que hacían parte de las logias

75. "Libro de Actas," 21 marzo, 1879. PHA, Logia Luz. Hernández González, Manuel. "La Orden Cubana de los Caballeros de la Luz en el exilio norteamericano," en Masonería Española en América, (Zaragoza, 1993). 
Mt. Olive y Celestial de los Masones de Prince Hall. Ellos se unieron a estas logias y una vez completaron su iniciación solicitaron permiso para formar su propia logia.

Es importante anotar que si bien Marcus y Coronado no se afiliaron, o tal vez no pudieron hacerlo, a los Caballeros de la Luz, ellos no se agregaron simplemente a la creciente comunidad negra en medio de la que vivían. Y tampoco abandonaron el proyecto de una Cuba libre e igualitaria. En vez de eso, acudieron a una autoridad institucional negra estadounidense para formar una logia para hombres cubanos de color. La creación de una logia cubana particular al interior de los Masones de Prince Hall pudo haber sido un gesto de separación del más amplio contexto angloparlante en el que vivían (de sus cuñados y suegros) tanto como fue un gesto de independencia como hombres de color dentro del contexto cubano. Así, Schomburg llegó a Nueva York para encontrar una logia ya establecida, donde las ideologías masónicas de progreso, civilización y moralidad se solapaban con el nacionalismo cubano y la política racial independiente. ${ }^{76}$

Schomburg se unió a la logia Sol de Cuba poco después de llegar a Nueva York. ${ }^{77}$ Para 1910 había alcanzado liderazgo en dicha logia, sirviendo como secretario y posteriormente como Maestro. Fue en eventos masónicos, por ejemplo, donde conoció a John E. Bruce y a los demás hombres del Sunday Men's Club. Además, Sol de Cuba, después de 1910, evolucionó de una logia para latinoamericanos de color a una logia indistinguible de otras logias de Prince Hall en Brooklyn. En 1901 doce de los trece miembros de la logia listados en un reporte de la Gran Logia de Prince Hall tenían apellidos españoles, así como dos nuevos iniciados. ${ }^{78}$ En 1911, Schomburg apoyó el plan del Maestro Cladius Emanuel Cyril para incrementar el número de miembros de la logia atrayendo a negros angloparlantes. Cyril era un empleado postal que había nacido en Limón, Costa Rica, de padres jamaiquinos. Después de esta fecha la raza, no la lengua o la nacionalidad, sería la base principal de la membresía en Sol de Cuba. Para marcar esta transición, en 1914, la logia Sol de Cuba cambió oficialmente su nombre a Logia Prince Hall, conmemorando Prince Hall, el hombre negro de la Indias Occidentales que fundó la masonería negra a finales del siglo XVIII. Según Williamson, a medida que los miembros de la Logia número 38 se hacían crecientemente angloparlantes, "El hermano Schomburg tradujo

76. Estas conclusiones se basan en las listas de membresía de la logia de Sol de Cuba, SRBC, Williamson y el Censo Federal de los Estados Unidos para los años 1880 y 1900.

77. Según Williamson, Schomburg se asoció a la logia en 1892, pero su nombre no aparece ni en una lista de miembros de los años 1890 ni en el "Report of the Sol de Cuba Lodge No. 38 F. and A.M. to the Grand Lodge of the State of New York." 5 de junio, 1901. Ambos en SCRBC, Williamson.

78. Reporte de la Sol de Cuba Lodge No. 38. SCRBC, Williamson. 
todos sus documentos viejos del español al inglés, una tarea que requería una gran cantidad de tiempo y trabajo."

La participación de Schomburg en la masonería de Prince Hall en Harlem y Brooklyn era pues parte de un amplio arco histórico de relaciones entre comunidades multirraciales cubanas y puertorriqueñas e instituciones sociales negras multiétnicas antes de 1898. Después de 1898 la atracción de Schomburg por esta tradición más antigua, aun mientras otros veteranos de la emigración viraban hacia el socialismo era, en gran medida, reflejo de las actitudes de Schomburg con respecto a la clase y de las oportunidades que halló para satisfacer sus aspiraciones personales en clubes sociales negros de clase media. En sus memorias Bernardo Vega llevó a cabo un intento por apropiarse de la memoria de Schomburg para la historia de la clase obrera puertorriqueña organizada de Nueva York, enfatizando las amistades del joven Schomburg con activistas obreros como Flor Baerga. He argumentado también que Schomburg y otros intelectuales en el Partido Revolucionario Cubano que no eran de elite, muchos de ellos tabaqueros o tipógrafos autodidactas, tuvieron una relación íntima con el ala obrera del movimiento independentista, sirviendo como líderes e intermediarios de la membresía masiva de los clubes revolucionarios. Pero los intelectuales artesanos, negros, blancos y mulatos, también crearon sus propias instituciones sociales intermedias, clubes literarios, escuelas nocturnas y, en Brooklyn, he sugerido, una logia masónica. En estas instituciones, y en las tipografías de San Juan y Ponce, tipógrafos como Figueroa, Marín y Schomburg trabajaron para diseñar identidades públicas como autores y periodistas e igualmente como artesanos. En La Liga de Nueva York, artesanos de color invertían sus tardes en tareas de escritura y en conversaciones literarias y filosóficas con "El Maestro", José Martí, con el objetivo de avanzar hacia las profesiones. Su renuncia al sistema de castas era inseparable de sus propios proyectos de movilidad social mediante la autoeducación, el meticuloso comportamiento en público y el mérito individual. Se enfadaban con los "vicios" y "preocupaciones" de la sociedad colonial española, que impedían el reconocimiento íntegro de su hombría y virtudes. Schomburg estaba alineado con el activismo artesano en Puerto Rico y Nueva York, un activismo artesano basado en el ideal de que la movilidad individual no debería limitarse por el nacimiento. ${ }^{80}$

En efecto, Schomburg, como los hombres de La Liga, deseaba aparentemente ingresar a la élite relativamente pequeña de doctores, abogados y periodistas negros. Para 1901 se aseguró un empleo como oficinista legal y men-

79. Harry A. Williamson. "Arthur A. Schomburg: The Freemason." Manuscrito inédito fechado 13 de marzo, 1941. SCRB, Williamson.

80. Hoffnung-Garskof, “To abolish the law of castes.” Serra, Ensayos políticos (3ra serie). 
sajero en la firma Pryor, Mellis, y Harris, y le dijo a sus amigos que estaba "leyendo derecho" como preparación para el examen de New York State. En 1906, sin embargo, sus intentos de obtener un certificado en derecho fueron frustrados cuando no logró demostrar evidencias de suficiente educación escolar y el estado rehusó permitir que se presentara al examen.${ }^{81}$ Dolorosamente humillado, se acomodó entonces como un mensajero en Bankers Trust Company (aunque es curioso que en el censo de 1910 reportó estar empleado como "tipógrafo en un taller"). En Bankers Trust después llegó a ser jefe de la división de correspondencia internacional en la sala de correo. Este puesto difícilmente sería algo prestigiosos según los estándares de hoy y con seguridad estaba alejado de las ambiciones de Schomburg. Pero en los años 1910 aquel empleo estaba también alejado del mundo obrero de las fábricas de cigarros. Mientras los trabajadores de cigarros en las islas y en Nueva York enfrentaban la creciente presión de la mecanización en las primeras décadas del siglo, Schomburg observaba comprensivamente desde la comodidad y estabilidad relativas de un trabajo de oficina. ${ }^{82}$

Mientras ayudaba a que Sol de Cuba se integrara a la corriente dominante de la masonería angloparlante de Prince Hall, Schomburg se rodeó de hombres que compartían su estatus profesional y sus aspiraciones de clase. Por ejemplo, las listas de miembros de la vecina angloparlante Carthaginian Lodge en Brooklyn muestran una logia compuesta en su casi totalidad por trabajadores de oficina, funcionarios, administradores de nivel medio, empresarios o empleados postales. Las élites negras, tales como periodistas, educadores o doctores, estaban totalmente ausentes de las listas, así como los obreros comunes. Los trabajadores cualificados o artesanos eran tan solo una pequeña minoría. Las logias de Prince Hall en Brooklyn eran instituciones del estrato bajo de la clase media negra, un grupo cuyo estatus de clase como hombres negros respetables estaba definido por un rígido código de comportamiento en público. La membresía en las logias era selectiva y los miembros se vigilaban mutuamente, haciendo cumplir las nociones compartidas de moralidad, comportamiento y masculinidad. ${ }^{83}$

Los hermanos en las logias de Prince Hall glorificaban la imagen del "selfmade man", el hombre que ha logrado sus triunfos mediante sus propios esfuerzos. Este mensaje atraía a Schomburg. Se sentía a veces despreciado por

81. Des Verney Sinnette, Arthur Alfonso Schomburg, 35.

82. Schomburg entendió que, "the Cuban Negro, who laid the foundation of the great tobacco industries in the United States ... [has] been made useless and forced out, being substituted in a large measure by the whites and modern machinery." Carta de Schomburg ta Mr. Ira de A. Reid, 18 de julio, 1935. SCRBC, Schomburg.

83. Summers, Martin. "Manliness and its Discontents: The Black Middle Class and The Transformation of Masculinity, 1900-1930." (Chapel Hill: University of North Carolina Press, 2004), 17-65. Muraskin, William A., Middle-class Blacks in a White Society: Prince Hall Freemasonry in America,. (Berkeley, CA: University of California Press, 1975), 25-42. 
intelectuales negros de élite, especialmente W. E. B. Du Bois y Carter Woodson, quienes dependían de su colección pero se negaban a aceptarlo como colega dado que no poseía un título académico. ${ }^{84}$ Schomburg expresó deliberadamente su actitud masónica hacia las élites negras en su discurso de 1913: "El graduado universitario está acostumbrado a sobreestimar su habilidad, recién salido de la maquinaría que le otorga un pergamino y lo corona con conocimiento, sale al mundo a encontrarse con el hombre práctico con años de experiencia y la madre ingenio." ${ }^{85}$ Fue entre hombres de la "madre ingenio" en San Juan que Schomburg inició su carrera como intelectual en Puerto Rico, y fue entre hombres de antecedentes y ambiciones similares que estableció su identidad étnica y de clase en la Nueva York negra.

Pero la masonería también contribuyó a satisfacer las ambiciones más altas de Schomburg, su deseo subversivo de sobresalir como líder e intelectual a pesar del racismo de la sociedad blanca y el esnobismo de la sociedad negra. Si la membresía en una logia ayudaba a asegurar respeto para hombres negros en los incómodos escalones más bajos de la clase media, convertirse en oficial, y luego ascender en la jerarquía masónica constituían una avenida para llegar a ser un negro notable o "líder racial." ${ }^{36}$ Tras servir primero como secretario y maestro de la logia Sol de Cuba, Schomburg ascendió rangos de la orden para convertirse, en 1918, en Gran Secretario de la Gran Logia Prince Hall del Estado de Nueva York y editor asociado de Masonic Quarterly Review. Durante las primeras décadas del siglo su éxito en los círculos masónicos le valió un reconocimiento más generalizado que su trabajo histórico. ${ }^{87} \mathrm{~A}$ la vez, el padrinazgo de Bruce, otro hombre de "madre ingenio" y los propios y notables logros de Schomburg como coleccionista también incrementaron gradualmente su fama en los círculos académicos, lo cual le trajo a Schomburg no pocas satisfacciones. En 1914, después de que Bruce ayudara para su elección a la American Negro Academy escribió: “iiiHe sido elegido como Académico!!! Eso es más importante que co-editor [Bruce acababa de ser nombrado co-editor emérito de Who's Who in Negro America de Bolívar]. Gracias por su buena carta de recomendación para la Academia." ${ }^{88}$ Dos años más tarde, cuando fue admitido a la American Bibliographer's Society, Schomburg volvió a escribir a Bruce: "Le agradezco por agregar más peso a mi cabeza ... al haber usado su buena voluntad eligiéndome para ser miembro de tan exclusiva sociedad." 89

Para los años 1930, tras vender su colección, retirarse del banco, publicar

84. Des Verney Sinnette, Arthur Alfonso Schomburg, 41, 190. Summers, Manliness and its Discontents, 1, 83-4.

85. Schomburg, Racial Integrity, 5-6.

86. Cayton, Horace and Drake, St. Claire. Black Metropolis. (Chicago: University of Chicago Press, 1940). 669-670, 688-715.

87. Watkins-Owens, Blood Relations, 73.

88. Carta de Schomburg a Bruce. Mayo, 1914. SCRBC, Bruce.

89. Carta de Schomburg a Bruce. 5 de septiembre, 1916. SCRBC, Bruce. 
varios artículos y servir como oficial en docenas de sociedades, Schomburg era ampliamente reconocido como un "líder racial", el estatus más alto disponible para un hombre negro de clase media en aquel entonces. Él había llevado a acabo una migración exitosa hacia las altas cumbres de la sociedad negra. A medida que tabaqueros e impresores en Puerto Rico formulaban su política cada vez más vinculada a los asuntos del trabajo, y a medida que Celso Barbosa continuaba abogando por el triunfo del mérito individual sobre los prejuicios de casta, Schomburg viraba hacia una filosofía victoriana de la elevación, del progreso racial dirigido por una clase media negra respetable. Su preocupación continua por el bienestar de los miembros menos privilegiados de la sociedad se manifestaba en trabajo caritativo con la Urban League e YMCA; no en el socialismo, la gestión sindical, o la política partidista..$^{90}$

La ascensión metódica del estatus lograda por Schomburg en los círculos sociales negros durante la primera década del siglo puede generar la idea de que se despojó gradualmente de sus características puertorriqueñas y se "convirtió" en afronorteamericano. Su papel en la traducción de la liturgia de la logia al inglés es tan solo el más prominente de los ejemplos de su hispanidad en atenuación después de 1898. Pero, paradójicamente, durante estos años fue precisamente la misma condición de extranjero de Schomburg, incluyendo su habilidad para las lenguas extranjeras, la que nutrió su avance social en la sociedad negra americana. En la década de 1920 The Negro World reportaba, con algo de celos, que los negros hispanohablantes se escapaban en gran parte de la segregación racial en los medios de transporte y otras acomodaciones impuestas a los nativos, y que muchos habían encontrado empleos preferenciales como asistentes contables, oficinistas, o en firmas de importación y exportación gracias a sus habilidades lingüísticas. ${ }^{91}$ Schomburg fue un ejemplo temprano de dicha tendencia. Capaz de establecer correspondencia en inglés, español y francés, ascendió por sí mismo en la sala de correos del Bankers' Trust Company hasta convertirse en director de la división de correspondencia con América Latina y el Caribe y supervisor de varios subordinados para cuando se jubiló en 1929. Por supuesto, no es una coincidencia que fuese promovido en el área que conocía mejor. Hombres cosmopolitas como Schomburg constituían recursos esenciales para las firmas de Wall Street a medida que los intereses financieros de Estados Unidos se filtraban en Puerto Rico, Cuba, Haití, República Dominicana y Centro América. Su empleo en la sala de correos no

90. Schomburg fue también miembro y a menudo ocupaba cargos oficiales en, The Urban League, the YMCA, Negro Society for Historical Research, the Association of Trade and Commerce, the Business and Professional Men's Forum, Harlem Citizens League for Fair Play, the NAACP, y varias fraternidades como Kappa Alpha Psi. Ortiz, Victoria. " Arthur A. Schomburg: A Biographical Essay" in The Legacy of Arthur A. Schomburg: A Celebration of the Past A Vision for the Future. (New York: The New York Public Library, 1986), 63.

91. The Negro World. 2 de julio, 1927 y 17 de julio, 1926. Ambos citados en Watkins-Owens, Blood Relations, 5. 
era glamuroso, pero cubría los gastos de Schomburg en su coleccionismo de libros, y le permitió, en su jubilación, viajar, escribir, y actuar como curador de su colección. Su acento extranjero pudo también haberle ayudado a escaparse de las restricciones impuestas por el color en lo que tenía que ver con la vivienda, permitiéndole comprar una casa en un barrio blanco de Brooklyn.

Igualmente, fue como corresponsal internacional y traductor que dejó su primera huella entre los masones. Por ejemplo, la primera posición importante que Schomburg obtuvo en la jerarquía del estado de Nueva York, de acuerdo con Harry A. Williamson, fue "presidente del Comité de la Gran Logia sobre Relaciones Internacionales," una presidencia nueva que la logia creó especialmente para él. En ese puesto estableció contactos con amigos masones en Santo Domingo, Haití y muchos países en Centro y Sur América, extendiendo el alcance del panafricanismo masónico. ${ }^{92}$ Schomburg ya tenía contactos en muchos de estos países desde sus días en el Partido Revolucionario Cubano. La idea de una comunidad de correspondencia internacional le era familiar desde sus más tempranos días como nacionalista. Además hablaba español con fluidez y podía leer francés. Tenía acceso a un mundo de masonería extranjera, historia internacional, $y$ hermandad racial ultramarina. A medida que el panafricanismo se expandía en Harlem y Brooklyn, Schomburg se convirtió a sí mismo en un eslabón indispensable con el mundo no angloparlante, explicando eventos en Cuba y traduciendo para hombres como Bruce y Garvey. Igualmente, su preeminencia como investigador histórico dependía a menudo de su estatus intermedio entre la Norteamérica negra y el mundo no angloparlante. Años más tarde viajó a España y Cuba, proporcionando archivos que eran ignorados por la mayoría de los académicos norteamericanos de entonces, bien fueran negros o blancos. Además, sostenía correspondencia con autores y comerciantes de libros por todo el mundo hispánico.

Schomburg ocupó un espacio entre los "crisoles de culturas" del Harlem y Brooklyn negros y el mucho más grande mundo negro extranjero más allá de ellos. Esta posición intermedia le ayudó a ganar estatus en la sociedad negra norteamericana, y le ayudó en la creación de su espectacular colección de documentos internacionales. Pero su historia no debería simplificarse a una celebración vacía de las ventajas de la etnicidad híbrida. Tampoco, yendo al caso, debería verse como un relato de privilegios especiales basado en un estatus extranjero y, por tanto, no del todo "negro." Los prejuicios raciales, las ansiedades de pertenencia nacional y desplazamiento, y la humillación en manos de élites educadas pudieron por sí solos haber hecho dolorosas las migraciones de Schomburg. La experiencia de hallarse entre culturas, con todas las ventajas que esto conllevaba, podía también convertirse con frecuencia en una fuente adicional de ansiedad y alienación. Aquí, nuevamente, el lenguaje es

92. Williamson. "Arthur A. Schomburg: The Freemason." SCRBC, Williamson. 
un ejemplo clave. La torpeza de Schomburg con el inglés, particularmente en forma escrita, era famosa. Si bien los amigos perdonaban su tortuosa prosa, atribuyéndola a su nacimiento extranjero, sus problemas escribiendo en inglés ayudaron a reforzar su rango secundario entre los intelectuales negros. Cuando publicó en periódicos importantes, Du Bois, Charles S. Johnson, Alain Locke y otros editores reescribían sus contribuciones con mano firme. Para ellos él era tan sólo un coleccionista y no un escritor o historiador sofisticado. "Mi buen y leal amigo Schomburg," escribió Locke mientras editaba un artículo de Schomburg en 1937, "puede reunir datos pero es incapaz de escribir. Fue formado en Puerto Rico en un español florido y su inglés es imposible." ${ }^{93}$

Al mismo tiempo, el español imperfecto de Schomburg, adormecido por los años de vida en el extranjero, era una fuente de vergüenzas cuando estaba entre intelectuales de hispanohablantes. El cubano negro Gustavo Urrutia, arquitecto y periodista, escribió, aparentemente sin ser conciente de la ofensa que esto podía causar, que cuando Schomburg visitó La Habana en 1932 “apenas recordaba su Castellano." ${ }^{4}$ Igualmente, Max Ríos, un profesor puertorriqueño en Columbia, bromeó con Schomburg sobre su uso accidental del spanglish en una carta dirigida a un comerciante de libros uruguayo pidiendo unos libros para su colección en la biblioteca pública. "Me doy cuenta de su error," escribió Ríos, "le tradujo del inglés la palabra "library", y puso "librería". Y "librería en español quiere decir "bookstore". Por eso le enviaron muchos ejemplares para la venta. Así que la risa era de usted." ${ }^{25}$ Para la década de 1930 Schomburg era admirado en ambas comunidades, la de habla inglesa y la de habla española, por su dominio de lenguas extranjeras. Pero dentro de cada comunidad sus credenciales estaban empañadas y, presumo, su orgullo humillado por frases torpes y usos imperfectos.

Schomburg, cuyo cosmopolitismo y etnicidad intermedia habían sido de gran ayuda en medio del panafricanismo de las décadas de 1910 y 1920, se hallaba frustrado con frecuencia afines de los años 1920 y comienzos de la siguiente década a medida que los intelectuales del Renacimiento de Harlem comenzaban a construir una identidad explícitamente norteamericana para Harlem y el nuevo movimiento artístico e intelectual negro. ${ }^{96} \mathrm{Si}$, como escribió Alain Locke en 1925, los rasgos culturales negros no eran "ni característicamente africanos ni algo que se explicaría como una herencia ancestral" sino "el resultado de su experiencia peculiar en [los Estados Unidos de] América,"

93. Cita de Des Verney Sinnette, Arthur Alfonso Schomburg, 172.

94. Gustavo Urrutia, "Imperialismo afrocubano" Diario de la Marina, 1 de marzo, 1936.

95. Carta de Max Rios a Schomburg, 22 de febrero, 1933.

96. Locke, Alain, "American Negro Musical Traditions" in The New Negro: An Interpretation, ed. Locke, 254. George Hutchison. The Harlem Renaissance in Black and White. (Cambridge: Belknap, 1995) 396-403, 435-448. 
¿dónde dejaba esto a los negros extranjeros como Schomburg? ¿dónde quedaba la causa del internacionalismo negro? La ira contenida de Schomburg sobre expresiones de este tipo de americanismo es evidente en su aguda respuesta a Ira de A. Ried, quien le había solicitado consejo en la escritura de su libro The Foreign Negro (1937). "Personalmente no estoy interesado en la perspectiva prejuiciosa sobre la procedencia de un hombre", escribió Schomburg, "entre más escucho a un hombre balbucear sobre nacimiento extranjero menos le estimo." Como extranjero, él quería ser reconocido como miembro íntegro de la comunidad de Harlem, como totalmente americano, y minimizar cualquier inquietud sobre orígenes nacionales, expresados con tanta frecuencia durante las décadas de 1920 y 1930 como prejuicios nativistas. "La nación americana abrió sus puertas a los nacidos en el extranjero y estas personas ayudaron en gran medida a hacer de la nación lo que realmente es hoy," le dijo a Ried. ${ }^{97}$ Al mismo tiempo, con todo, no deseaba renunciar a su internacionalismo y retrotraerse simplemente a una cultura negra norteamericana introspectiva y de habla inglesa. De hecho, después de más de treinta años en Nueva York, y dos décadas de aislamiento de los intelectuales cubanos, Schomburg comenzó a reafirmar sus propios orígenes hispánicos y trató de reavivar el interés de los norteamericanos negros por el resto del mundo negro. Este esfuerzo parece haberse agudizado tras su viaje a Cuba en 1932, cuando fue allí en busca de "libros negros" y se presentó a algunos de los mismos cubanos de color cuyo liderazgo continuo había desaparecido de su vista tras la "guerra racial" de 1912. Visitó a Juan Gualberto Gómez (a quien llamaba viejo amigo), a Lino D’Ou, al General Campos Marquetti (que también puede haber conocido en Nueva York en los 1890), a Gustavo Urrutia y al joven poeta Nicolás Guillén. En un estallido de entusiasmo renovado imaginó una vez más la construcción de un eje de vida intelectual y cultural entre comunidades de color de Cuba y Nueva York. "Para los negros americanos," escribió, "interesados en el desarrollo cultural de su raza, un viaje a Cuba sería una inspiración y una revelación que podría asombrarlos."98 Pero en la cúspide de su fama como líder racial estaba dolorosamente fuera de tono con el ánimo de los intelectuales de Harlem. Planeó fracasados viajes en barco a Cuba y Haití. ${ }^{99}$ Trató desesperadamente de hallar a alguien que tradujera los trabajos de Nicolás Guillén, y de llevar a Guillén a Nueva York. ${ }^{100}$ Hospedó en su casa de Brooklyn al pintor cubano Pastor

97. Carta de Schomburg a Mr. Ira De A. Reid, 18 de julio, 1935. SCRBC, Schomburg.

98. Schomburg, Arthur A., "My Trip To Cuba in Quest of Negro Books." Opportunity. Febrero, 1933. 50.

99. Carta de Claude A. Barnett (director del Chicago Defender) a Schomburg. 22 de noviembre, 1932. Carta de Dantes Bellegarde (diplomático haitiano) a Schomburg, 22 de mayor, 1934. Carta de Gustavo Urrutia a Schomburg (sin fecha), Varias cartas de introducción de Schomburg a Bellegarde, Urrutia, y Stenio Vincent. SCRBC, Schomburg.

100. Carta de Edna Worthy Underwood a Schomburg, 29 marzo, 1933. Carta de Schom- 
Argudín durante casi un año y salió lanza en ristre contra el provincialismo de "los llamados artistas negros de [esta] ciudad" quienes "no tenían la cortesía de invitar al distinguido pintor cubano a una recepción o a tomar té. Son de tal modo exclusivistas y prejuiciosos", escribió a Catarina Jarboro en Francia, "que he renunciado a tener algo que ver con ellos."101 Durante sus últimos años vivió entre sus libros y con sus cartas, emergiendo ocasionalmente para dar discursos o asistir a cenas para recaudación de fondos. En su correspondencia con Urrutia y otros amigos cubanos reavivó su sentido de pertenencia a la clase cubana de color. En documentos y artículos posteriores continuó ensamblado la imagen de una diáspora africana históricamente unificada pero internacionalmente dispersa, una imagen que había, por el momento, cesado de resonar en la vida étnica de la ciudad que lo rodeaba.

\section{Conclusión:}

Si bien es de muchas formas inusual, la historia de Schomburg nos ayuda a repensar la evolución de la identidad étnica y racial puertorriqueña en Nueva York como un proceso de formación de comunidad relativamente abierto. Comprender este proceso comienza, tal como lo sugiere Winston James, con la comprensión de los diferentes sistemas raciales que han operado en Puerto Rico, en las islas Británicas y los Estados Unidos. Requiere además prestar una atención académica mucho más seria a la evolución de fuertes líneas de demarcación entre grupos étnicos negros y puertorriqueños entre las décadas de 1930 y 1960, enfrentando la cuestión de cómo (y si es que así fue) se volvió posteriormente difícil ser negro y puertorriqueño simultáneamente en Nueva York. Pero en el interior de estos dos grupos generales de inquietudes históricas, Schomburg nos recuerda que deberíamos también comenzar a examinar cómo los puertorriqueños (como otros grupos étnicos y raciales en Nueva York y el Caribe) interpretaron y negociaron sus propias identidades localmente y de maneras impredecibles, a menudo contrapuestas a nuestra percepción general de las ideologías raciales que operaban en Puerto Rico y Nueva York. Schomburg no puede convertirse en un arquetipo de resistencia puertorriqueña al racismo en el Caribe hispánico o en la Nueva York hispánica. Prestar de nuevo atención a su vida puede dar inicio a un análisis más atento de las tensiones sobre raza entre los nacionalistas puertorriqueños en Nueva York, y de las

burg a Guillén, 1 de noviembre, 1932, 28 de febrero, 1938, y 29 de abril, 1938. Cartas de Richard Patee a Schomburg, 3 y 7 de mayor, 1938. Carta de Guillén a Schomburg, 7 de noviembre, 1937 and 2 de febrero, 1938. SCRBC, Schomburg.

101. Carta de Schomburg a Catarina Jarboro. 9 de junio, 1936. Cartas entre Pastor Argudín and Schomburg, 1932-1934. Carta de Urrutia a Schomburg 29 de agosto, 1934 and 9 de septiembre, 1935, Carta de Schomburg a Urrutia (sin fecha). Todos en SCRBC, Schomburg. 
alianzas que algunos puertorriqueños de color forjaron con cubanos y aun con norteamericanos negros en los márgenes que se solapaban en sus comunidades e instituciones.

En cierta forma esto proyecta hacia el pasado la percepción de Juan Flores de que una relación especial con la gente negra y la cultura negra está en el centro de la identidad puertorriqueña en Nueva York. ${ }^{102}$ Pero el "momento de ramificación" que Flores examina entre los poetas continentales puertorriqueños de la era de los movimientos de derechos civiles (años 60) no era el mismo que el momento de Schomburg. Sus migraciones fueron el producto de un momento específico de diásporas que se solapaban en el mundo Atlántico. Su migración a la Norteamérica negra fue facilitada por un estrecho encuentro entre el mundo multirracial del nacionalismo antillano y el mundo multiétnico de las instituciones negras. Schomburg no acudió a los norteamericanos negros como un puertorriqueño oprimido en busca de aliados. Acudió a los norteamericanos negros como un "negro" nacido en Puerto Rico. Él y otros en el pequeño y temprano enclave puertorriqueño en Nueva York se habían ya aliado con cubanos de color en el Partido Revolucionario Cubano en Nueva York y con negros norteamericanos en la logia masónica Sol de Cuba. Era aceptado en círculos panafricanistas norteamericanos, no porque los puertorriqueños fueran vistos como aliados naturales sino porque, de acuerdo con la filosofía racial que allí se albergaba, los negros extranjeros eran familia, estaban emparentados por la sangre. Se convirtió en un respetado líder racial no porque se hubiera convertido en un asimilado negro "americano" de forma inmediata, sino porque al tener un español fluido y ser competente en francés Schomburg podía servir como corresponsal y traductor entre negros en los Estados Unidos y una red de intelectuales negros que surgieron dentro del nuevo orden imperial de la cuenca Atlántica. Obtuvo prestigio en las instituciones de la Nueva York negra precisamente por tratarse de alguien a caballo entre el extranjero y el norteamericano negro. Obtuvo prestigio entre los negros del Caribe al convertirse en un líder racial en el centro de la clase media negra más rica y poderosa del mundo.

La conciencia histórica y racial que construyó en este mundo de cambiante y desplazada identidad, un mundo dominado por el racismo y el creciente poder imperial de los Estados Unidos, no es sólo importante para reajustar nuestra percepción de la migración y etnicidad puertorriqueñas tempranas o para revisar nuestra comprensión de la biografía peculiar de Schomburg. De sus lealtades internacionales y etnicidad híbrida, Schomburg, el lector ávido y prolífico coleccionista, construyó el archivo por el cual los historiadores lo

102. Flores, Juan “'Qué Assimilated, Brother, Yo Soy Asimilao': The Structuring of Puerto Rican Identity in the U.S." in Challenging Fronteras: Structuring Latina and Latino Lives in The U.S.: An Anthology of Readings. eds. Mary Romero, Pierrette Hondagneu-Sotelo, and Vilma Ortiz (New York: Routledge, 1997), 175-185. 
recuerdan con aprecio. Al negociar su propia identidad como indiano occidental en Puerto Rico, como puertorriqueño en el movimiento de independencia cubano, y como negro extranjero en Harlem y Brooklyn, sentó las bases para la idea de una diáspora africana que hemos heredado. Nos legó una colección moldeada no sólo por su visión cosmopolita de la raza, sino también por sus amistades, correspondencia y viajes en el mundo Atlántico. Comprender las migraciones de Arturo Schomburg, y las peculiaridades del mundo que habitó, nos ayuda a entender el surgimiento de la idea de una diáspora negra que tenía a Nueva York como su centro. Sus migraciones ayudan a explicar cómo Harlem se convirtió en el centro de la investigación sobre cultura negra internacional, en vez de La Habana, Puerto Príncipe, Salvador de Bahía o Johannesburgo. 